\title{
Impact of Some Postharvest Safe Treatments on Maintaining Quality and Extending Life of Guava Fruits during Cold Storage
}

\author{
A.F. Abd El-Khalek \\ Horticulture Department, Faculty of Agriculture, Tanta University, 31527. Egypt.
}

\begin{abstract}
D ESPITE the increase in guava growing area, improvement in postharvest quality is still negligible. The influence of putrescine (PUT), hydroxypropyl methylcellulose (HPMC) and their combinations on postharvest life and fruit quality of 'Maamoura' guavas was evaluated for two consecutive seasons (2016 and 2017). The experiment included six postharvest treatments, distilled water (control), $1 \mathrm{mM}$ PUT, $2 \mathrm{mM}$ PUT, 5\% HPMC, $1 \mathrm{mM}$ PUT incorporated with $5 \%$ HPMC and $2 \mathrm{mM}$ PUT incorporated with 5\% HPMC. These treatments were performed by immersing guava fruits for five minutes. Treated and control fruits were stored at $7 \pm 1{ }^{\circ} \mathrm{C}$ and $90 \pm 5 \%$ relative humidity (RH) for 24 days. The changes in physical and chemical characteristics of guava fruits were determined every eight days of cold storage. Results of this study indicated that, all postharvest treatments of 'Maamoura' guavas reduced the deterioration in physical and chemical characteristics as compared to untreated fruits (control). In addition, combined treatments of PUT at 1 or $2 \mathrm{mM}$ and 5\% HPMC were superior than individual treatments. These treatments significantly minimized physiological loss in weight, reduced decay incidence and maximized marketable percentage as well as maintained fruit firmness and visual appearance score during storage. Moreover, these applications significantly delayed colour development by retained total chlorophyll content as well as significantly maintained fruit contents in ascorbic acid and titratable acidity and also significantly slowed the accumulation of fruit contents in total soluble solids and total soluble solids/titratable acidity ratio during cold storage period. Ultimately, these applications significantly prolonged the shelf life period for guavas at ambient conditions $\left(25 \pm 2{ }^{\circ} \mathrm{C}\right.$ and $\left.65 \pm 5 \% \mathrm{RH}\right)$ after the end of cold storage period (24 days) as compared to control. In particular, postharvest application of PUT at $2 \mathrm{mM}$ incorporated with $5 \%$ HPMC of guavas was the most effective in this aspect than the other treatments and control. Therefore, this application is a promising method for alleviating decay, preserving quality and extending postharvest life period of 'Maamoura' guava fruits during cold storage.
\end{abstract}

Keywords: Maamoura guavas, Putrescine, Hydroxypropyl methylcellulose, Postharvest, Decay, Fruit quality, Chlorophyll, Storage life.

\section{Introduction}

Guava (Psidium guajava L.) is considered as one of the important tropical and subtropical fruits of the world. Guava is a highly palatable fruit and is a rich source of vitamin $\mathrm{C}$, carotene, thiamine, antioxidants and both calcium and phosphorus (Pérez-Gutiérrez et al., 2008). In Egypt, guava is one of the most common and important commercial fruit crops and is very popular due to its' cheap price compared with other fruits. It is grown in about 37343 feddans, out of which 32674 feddans are fruiting, yielding about 339520 tons (Anonymous, 2017). Guava is a highly perishable fruit and is susceptible to mechanical damage due to it's delicate skin which offers very little protection against injury, which may lead to the development of several diseases such as soft rot and anthracnose resulting in problems during storage and limiting the postharvest storage life (Kader, 2002 and Jain et al., 2003). It is also a climacteric fruit with elevated respiratory activity and high rate of ethylene production and consequently leading to fast ripening and senescence processes (Jain et al., 2003). However, during the storage of guava the marketability of fruits is lost rapidly owing to it's quick softening, discolouration and rotting (Reyes \& Paul, 1995 and Jain et al., 2003). Thus, it is necessary to find out feasible solutions to extend storage life, slow down ripening and preserve postharvest quality of guava fruits after

Corresponding author: e-mail: ahmed5474946@yahoo.com 
harvesting. Various safe techniques of low cost and high efficiency could be used in this respect as polyamines applications, edible coatings and storing fruits at low temperature they all targeted to reduce transpiration, ripening process, spoilage and fruit senescence (Dhall, 2013 and Razzaq et al., 2014).

Polyamines are low molecular weight small aliphatic amines that are ubiquitous in living organisms and have been implicated in a wide range of biological processes including plant growth, development and response to stress (Smith, 1985). They are found as cations in every plant cell at the physiological $\mathrm{pH}(5-6)$ and are able to bind to several negatively charged molecules such as proteins, phospholipids, pectic polysaccharides and the nucleic acids as well as that can be conjugated to various phenolic acids to produce plant defense related compounds (Walters, 2003). Polyamines are metabolites that utilize a common precursor S-adenosyl methionine (SAM) and thus can inhibit ethylene biosynthesis by competing with ethylene for the precursor SAM (Paksasorn et al., 1995 and Pandey et al., 2000). Moreover, polyamines significantly decrease ethylene biosynthesis by inhibiting the activities of 1-aminocyclopropane-1-carboxylic acid synthase (ACS) and 1-aminocyclopropane1-carboxylic acid oxidase (ACO) enzymes in fruits (Valero et al., 2002 and Khan et al., 2007). In addition, polyamines play a vital role in the antioxidant defense system by increasing the total antioxidant activity, thus providing protection to membranes against the oxidative injury caused by reactive oxygen species (Khan et al., 2008 and Razzaq et al., 2014). Polyamines were also reported to be effective anti senescent agents (Pandey et al., 2000 and Valero et al., 2002), which were found to delay the softening and retard chlorophyll loss in fruits (Valero et al., 2002 and Razzaq et al., 2014). The levels of polyamines are abundant in young tissues then decline to lower levels during prolonged storage and ripening while the tissues go through the senescence and this diminution affects the physiological processes and storage life of fruits (Valero et al., 2002). The most common polyamines are diamine putrescine (PUT), triamine spermidine (SPD) and tetraamine spermine (SPM), which are biosynthesized from the decarboxylation of arginine and catalyzed by arginine decarboxylase or arginase and ornithine decarboxylase (Morris, 2009).

Egypt. J. Hort. Vol. 45, No.2 (2018)
Exogenous application of PUT has been reported to enhance storage life, delay fruit ripening, increase the total antioxidant activity and reduce decay incidence without impairing fruit quality of various climacteric and nonclimacteric fruits such as lemons (Valero et al., 1998), peaches (Martínez-Romero et al., 2000), apricots (Martínez-Romero et al., 2002 and Khosroshahi \& Esna-Ashari, 2007), plums (Serrano et al., 2003, Khan et al., 2007 and Khan et al., 2008), pomegranates (Mirdehghan et al., 2007 and Barman et al., 2011) and mangoes (Malik \& Singh, 2005, Jawandha et al., 2012 and Razzaq et al., 2014).

Edible coatings are considered as environmental friendly tools that enable extending the postharvest life of many products including fresh fruits and vegetables. They form a semi-permeable barrier to gases and water vapor, thereby reducing respiration and weight loss as well as preventing physical damage and enhancing appearance of fruits and vegetables. Furthermore, edible coatings decrease metabolic processes and ethylene production rate, thus delaying ripening and senescence processes of fruits (Olivas et al., 2008 and Dhall, 2013). Hydroxypropyl methylcellulose (HPMC) is one of the most common commercially produced cellulose derivatives, having different permeabilities to water vapor, gases and is a good film former on fresh fruits and vegetables (Olivas et al., 2008). HPMC is classified as Generally Recognized As Safe (GRAS) by the European Food Safety Authority and the United States Food and Drug Administration and is considered as an edible coating (Valencia-Chamorro et al., 2008).

Exogenous application of HPMC on mangoes cv. 'Tommy Atkins' was effective in controlling decay incidence, reducing weight loss and delaying ripening process of fruits during storage at $10-15^{\circ} \mathrm{C}$ (Baldwin et al., 1999). The application of different coating formulations containing carnauba wax, shellac, zein and cellulose derivatives decreased the respiration rate, reduced development of external and internal colour and delayed fruit ripening in 'Kent', 'Tommy Atkins' and 'Lirfa' mango fruits especially coatings based upon HPMC (Hoa et al., 2002). Coated mandarins with HPMC lipid composite was used to maintain postharvest quality of fruits during cold storage (Pérez-Gago et al., 2002 and Navarro-Tarazaga et al., 2008). Moreover, HPMC lipid composite edible coatings and food preservatives as 
antifungal ingredients can effectively alleviate disease incidence, reduce weight loss rate and maintain rind firmness of coated citrus fruits during storage (Valencia-Chamorro et al., 2008, Valencia-Chamorro et al., 2009 and ValenciaChamorro et al., 2011) and tomatoes (Fagundes et al., 2014).

Therefore, the objective of the present investigation was to evaluate the impact of postharvest applications of putrescine, hydroxypropyl methylcellulose and their combinations on maintain the quality attributes and extending life of 'Maamoura' guava fruits during cold storage at $7 \pm 1{ }^{\circ} \mathrm{C}$ and $90 \pm 5 \%$ relative humidity (RH).

\section{Materials and Methods}

\section{Fruit material}

The present study was carried out during 2016 and 2017 seasons at laboratory of Horticulture Department, Faculty of Agriculture, Tanta University, Egypt. 'Maamoura' guava trees are grown in Metoubes, Kafr El-Sheikh Governorate, Egypt (latitude, $31^{\circ} 29^{\prime} \mathrm{N}$, longitude, $30^{\circ} 52^{\prime} \mathrm{E}$ ). Guava trees were about 23 years of age, planted at a spacing of $5 \times 5$ meters apart in a loamy clay soil under flooding irrigation and subjected to standard agriculture practices recommended by ministry of agriculture and land reclamation. Guava fruits were picked from a private orchard at maturity stage (yellowish green) in the second week of August according to Mercado-Silva et al. (1998) from almost similar trees and guavas apparently uniform in size and free of visible symptoms of infection.

\section{Postharvest treatments and storage}

In both experimental seasons, 'Maamoura' guava fruits were transferred to the Horticulture laboratory immediately after harvesting in plastic boxes (15 kg capacity). On arrival, the fruits were cleaned, sorted, graded and the detective fruits including wounded and other disorders were excluded.

Putrescine (PUT) aqueous solution at 1 $\mathrm{mM}$ and $2 \mathrm{mM}$ was prepared in distilled water. Hydroxypropyl methylcellulose (HPMC) was prepared as described by Valencia-Chamorro et al. (2008). Briefly, an aqueous solution of HPMC $(5 \% \mathrm{w} / \mathrm{v})$ was prepared by dispersing the HPMC in distilled water at $90^{\circ} \mathrm{C}$ for two hours. After cooling to $20^{\circ} \mathrm{C}$, glycerol monostearate was added to the solution as a plasticizer to improve the strength and flexibility of the coating solutions. Ratio of HPMC-glycerol (2:1) (dry basis). Sample was homogenized with a mixer for $4 \mathrm{~min}$ at $12500 \mathrm{rpm}$ and later hydration overnight at room temperature $\left(25 \pm 2^{\circ} \mathrm{C}\right)$ to ensure complete hydration of the HPMC. For the incorporated treatments, PUT at either $1 \mathrm{mM}$ or $2 \mathrm{mM}$ was added into an aqueous solution of HPMC after the preparation of HPMC $(5 \% \mathrm{w} / \mathrm{v})$. Distilled water without any additives was used as untreated treatment (control).

The sound fruits at the same maturity stage were washed with $0.01 \%$ sodium hypochlorite water solution for 2 minutes to clean the surface of fruits and then air dried at room temperature until visible moisture on fruit surfaces disappeared completely. A total of 810 clean sound fruits were selected and randomly divided into six treatments with three replicates. Guava fruits were subjected to the following treatments: (1) distilled water used for untreated fruits (control treatment), (2) PUT at $1 \mathrm{mM}$, (3) PUT at $2 \mathrm{mM}$, (4) edible coating of HPMC at $5 \%$, (5) PUT at 1 $\mathrm{mM}$ incorporated with 5\% HPMC and (6) PUT at $2 \mathrm{mM}$ incorporated with 5\% HPMC.

Postharvest treatments were performed by dipping fruits in the previous treatments for five minutes in five liter of aqueous solutions containing Tween- 80 at a concentration of $0.05 \%$ $(\mathrm{v} / \mathrm{v})$ to improve wettability and adherence to guavas surface. After dipping treatments, the fruits were allowed to dry for 30 minutes at room temperature by electric fan. After that, the fruits in each treatment were packed in foam plates covered with perforated polyethylene sheets with a thickness of $0.04 \mathrm{~mm}$ and then packaged in cardboard boxes with dimensions of $45 \times 35 \times 10$ $\mathrm{cm}$. All experimental boxes were stored at $7 \pm 1{ }^{\circ} \mathrm{C}$ and $90 \pm 5 \%$ RH for 24 days. Fruit physical and chemical characteristics were examined at harvest time and then every eight days intervals of cold storage period.

\section{Assessments performed}

Fruit physical characteristics

Weight loss percentage: it was calculated by the following formula: [(fruit weight before storage - fruit weight after each period of cold storage) / fruit weight before storage] $\times 100$.

Decay percentage: it was recorded every eight days of cold storage by counting the number of decayed fruits due to fungus or any microorganisms infection and calculated as a percentage of the initial number of stored fruits 
using the following equation: (number of decayed fruits at specified storage period / initial number of stored fruit) $\times 100$.

Marketable percentage: it was calculated by the following formula: (weight of sound fruits at specified storage period / initial weight of fruits) $\times 100$.

Visual appearance was measured by a rating system, fruit scored: very $\operatorname{good}=9$, $\operatorname{good}=7$, acceptable $=5$, unacceptable $=3$ and poor $=1$

Firmness was measured in three guava fruits per replicate at two equatorial sites to determine the penetration force by using a hand-held fruit firmness tester (FT-327, Italy) equipped with an 8 mm cylindrical stainless steel plunger tip (Watkins and Harman, 1981). Two readings were taken on the flesh of each fruit after peeling. The firmness value was expressed in terms of kilogram force (kgf) and data was calculated as Newton (N) by the following formula ( $1 \mathrm{~N}=0.1 \mathrm{kgf})$.

\section{Fruit chemical characteristics}

\section{Fruit pigments}

Chlorophyll and carotenoid contents in the pulp of guavas (three replicates) were spectrophotometrically determined according to the method of Wellburn (1994). The absorbance of the extract was measured at a spectrum of 663 $\mathrm{nm}$ for chlorophyll a, $646 \mathrm{~nm}$ for chlorophyll b and 470 for carotene by using a spectrophotometer (UV1901PC spectrophotometer). Pigment contents were calculated by the following equations:

Chlorophyll $a(\mu \mathrm{g} / \mathrm{ml})=12.21 \mathrm{E}_{663}-2.81 \mathrm{E}_{646}$

Chlorophyll $b(\mu \mathrm{g} / \mathrm{ml})=20.13 \mathrm{E}_{646}-5.03 \mathrm{E}_{663}$

Total chlorophyll $(\mu \mathrm{g} / \mathrm{ml})=$ chlorophyll $a+$ chlorophyll $b$

Total carotenoids $(\mu \mathrm{g} / \mathrm{ml})=\left[\left(1000 \mathrm{E}_{470}\right)-(3.27 \times\right.$ chlorophyll $a+104 \times$ chlorophyll $b)] / 198$

Where $\mathrm{E}=$ Optical density at the indicated spectrum length and results were expressed as $\mathrm{mg} / 100 \mathrm{~g}$ of fresh weight (fw) as follows: [(Resulting value from each equation $\times$ volume extract $) /(1000 \times \mathrm{fw})] \times 100$.

Ascorbic acid, total soluble solids (TSS), titratable acidity (TA) and TSS/TA ratio in pulp

After each of cold storage period, fifteen guava fruits from each treatment (three replicates) were extracted by crushing the pulp of fruits, then the juice strained through a muslin cloth and used for measuring internal fruit quality as follow:

Fruit ascorbic acid analysis was estimated according to AOAC (2005). Samples of fruit juice were used, oxalic acid solution was added to each sample and titrated with 2,6-dichlorophenol-indophenol dye solution and expressed as a milligram of ascorbic acid and was calculated as $\mathrm{mg} / 100 \mathrm{ml}$ of the juice.

Fruit TSS content was measured using a hand refractometer, 0-32 scale (ATAGO N-1, Japan) and expressed in ${ }^{\circ}$ Brix after making the temperature correction at $20^{\circ} \mathrm{C}$ according to AOAC (2005).

Fruit TA was assayed based on the method of adopting the procedure described by AOAC (2005). Aliquot of fruit juice was taken and titrated against $0.1 \mathrm{~N} \mathrm{NaOH}$ in the presence of phenolphthalein as an indicator to the end point and expressed as a percentage of citric acid.

Fruit TSS/TA ratio was calculated from the values recorded for fruit juice TSS and TA percentages determined.

\section{Shelf life period (days)}

After 24 days of cold storage at $7 \pm 1^{\circ} \mathrm{C}$ a guava fruit sample from each replicates was taken out and placed at ambient conditions $\left(25 \pm 2^{\circ} \mathrm{C}\right.$ and $\left.65 \pm 5 \% \mathrm{RH}\right)$ till bad appearance or rotting occurs. Then, the number of days was recorded which was considered as shelf life period for guava fruits.

Experimental design and statistical data analysis

This experiment was arranged in a completely randomized design having three replicates and consisting of two factors, postharvest treatments and storage period. This experiment was analysis as factorial experiment. Data calculated as percentage were transformed to arcsine of square root before statistical analysis and non-transformed means are shown as they are. The effects of postharvest treatments and cold storage period on different attributes were analyzed statistically by analysis of variance (ANOVA) using the MSTAT-C statistical package (M-STAT, 1993). Comparisons between means were done by Duncan's multiple range test $(\mathrm{DMRT})$ at probability $\leq 0.05$ according to Duncan (1955). 


\section{Results and Discussion}

Effect of postharvest applications of putrescine (PUT), hydroxypropyl methylcellulose (HPMC) and their combinations on weight loss, decay and marketable percentages of 'Maamoura' guava fruits during cold storage

Data in Tables 1, 2 and 3 demonstrate that weight loss and decay percentage of 'Maamoura' guavas gradually and significantly increased with the progress of cold storage period at $7^{\circ} \mathrm{C}$ in both seasons. On contrast, guava fruits showed a gradual and significant reduction in marketable percentage with the advancement of cold storage period in both seasons. Our results in this study indicated that, maximum weight loss $(10.72$ \& $11.34 \%)$ and decay percentage (24.60 \& $28.13 \%)$ of 'Maamoura' guavas were observed at the end of storage period in the first and second seasons, respectively as well as it recorded the minimum marketable fruits percentage (64.41 \& $61.11 \%$ ) in 2016 and 2017 seasons, respectively.

Also on the average data reveal that, postharvest applications of PUT, HPMC and their combinations showed significant lower percentages of fruit weight loss and decay comparison with untreated fruits (control). On contrary, all treated 'Maamoura' guava fruits showed significant higher percentage of marketable fruits than control in the two seasons. In addition, dipped 'Maamoura' guava fruits in 1 or $2 \mathrm{mM}$ PUT incorporated with $5 \%$ HPMC for five minutes were more effective in reducing weight loss and decay percentages as well as increasing the percentage of marketable fruits than individual applications during cold storage period at $7^{\circ} \mathrm{C}$.

Postharvest application of $2 \mathrm{mM}$ PUT incorporated with 5\% HPMC of 'Maamoura' guavas recorded the lowest fruit weight loss percentage (4.07 \& $3.94 \%)$ and decay percentage $(2.38 \& 2.38 \%)$ as well as the highest marketable fruits (92.98 \& $93.69 \%$ ) in 2016 and 2017 seasons, respectively. On contrary, untreated fruits (control) exhibited the highest fruit weight loss $(9.25 \& 10.51 \%)$ and decay percentage $(23.81 \& 24.33 \%)$ as well as recorded the lowest marketable fruits percentage (66.99 \& $64.62 \%$ ) in the first and second seasons, respectively.

The interaction effect between postharvest applications and storage periods showed significant differences at $p \leq 0.05$ for weight loss, decay and marketable percentages of 'Maamoura' guava fruits in both seasons under this study. Data declare that, combined treatments of PUT and HPMC significantly delayed the decay incidence of guavas up to 16 days of cold storage at $7^{\circ} \mathrm{C}$ as compared to individual treatments and untreated fruits (control) in both seasons. Our results in this study indicated that, at the end of cold storage period (24 days), treated 'Maamoura' guava fruits with $2 \mathrm{mM}$ PUT plus 5\% HPMC recorded the significant lowest of fruit weight loss percentage $(7.58 \& 7.92 \%)$ and decay percentage $(9.52 \&$ $9.52 \%$ ) with the significant highest of marketable fruits percentage $(80.61 \& 82.61 \%)$ in the first and second seasons, respectively. On the opposite, untreated fruits (control) showed the significant highest of fruit weight loss percentage $(17.84 \&$ $18.71 \%)$ and decay percentage (52.38 \& 59.24 $\%$ ) with the significant lowest of marketable fruits percentage (28.55 \& $24.19 \%$ ) in 2016 and 2017 seasons, respectively.

The loss of fruit weight during cold storage is caused by water exchange between the internal and external atmosphere, the transpiration rate being accelerated by cellular breakdown (Woods, 1990). The increases in physiological loss of weight and decay incidence as well as a decrease in marketable of guavas with the progress of cold storage are attributing to the increase in transpiration rate, ethylene production and cellular breakdown of fruits (Barman et al., 2011 and Razzaq et al., 2014).

Polyamines are metabolites that utilize a common precursor of ethylene biosynthesis, S-adenosyl methionine (Smith, 1985). It was believed that polyamine biosynthesis would negatively affect ethylene biosynthesis due to competition for a common substrate and therefore inhibit ripening of fruits (Valero et al. 2002 and Khan et al., 2007). Thus, polyamines act as anti senescent agents, reduce respiration rate, delay ethylene production and induce mechanical resistance (Valero et al., 2002 and Razzaq et al., 2014).

Anti pathogenic function of polyamines has been reviewed by Walters (2003), who reported that polyamines conjugated to phenolic compounds and hydroxycinamic acid amides and have shown a good correlation between accumulation of hydroxycinamic acid amides and pathogen resistance. Furthermore, added that polyamines induce pathogenesis related proteins. 
TABLE 1. Effect of postharvest applications of putrescine (PUT), hydroxypropyl methylcellulose (HPMC) and their incorporations on weight loss percentage of 'Maamoura' guava fruits during cold storage at $7 \pm 1^{\circ} \mathrm{C}$ and $90 \pm 5 \%$ RH

\begin{tabular}{|c|c|c|c|c|c|c|c|}
\hline \multirow{3}{*}{ Postharvest applications } & \multicolumn{6}{|c|}{ Storage period (days) } & \\
\hline & $\mathbf{0}$ & & 8 & & 16 & 24 & \multirow[t]{2}{*}{ Means } \\
\hline & \multicolumn{6}{|c|}{ Season 2016} & \\
\hline Distilled water (control) & $0.00 \mathrm{i}$ & 6.09 & ef & 13.10 & & $17.84 \mathrm{a}$ & $9.25 \mathrm{~A}$ \\
\hline $1 \mathrm{mM}$ PUT & $0.00 \mathrm{i}$ & 5.81 & efg & 7.33 & de & $10.45 \mathrm{c}$ & $5.90 \mathrm{~B}$ \\
\hline $2 \mathrm{mM}$ PUT & $0.00 \mathrm{i}$ & 4.41 & fgh & 6.28 & ef & $10.14 \mathrm{c}$ & $5.21 \mathrm{BC}$ \\
\hline $5 \%$ HPMC & $0.00 \mathrm{i}$ & 4.12 & fgh & 6.00 & ef & $9.24 \mathrm{~cd}$ & $4.84 \mathrm{BC}$ \\
\hline $1 \mathrm{mM}$ PUT incorporated with 5\% HPMC & $0.00 \mathrm{i}$ & 3.46 & $\mathrm{gh}$ & 5.75 & efg & $9.08 \mathrm{~cd}$ & $4.58 \mathrm{C}$ \\
\hline $2 \mathrm{mM}$ PUT incorporated with 5\% HPMC & $0.00 \mathrm{i}$ & 3.20 & $\mathrm{~h}$ & 5.51 & $e-h$ & $7.58 \mathrm{de}$ & $4.07 \mathrm{C}$ \\
\hline \multirow[t]{2}{*}{ Means } & $0.00 \mathrm{D}$ & 4.52 & $\mathrm{C}$ & 7.33 & $\mathrm{~B}$ & $10.72 \mathrm{~A}$ & \\
\hline & \multicolumn{6}{|c|}{ Season 2017} & \\
\hline Distilled water (control) & 0.001 & 8.98 & de & 14.35 & & $18.71 \mathrm{a}$ & $10.51 \mathrm{~A}$ \\
\hline $1 \mathrm{mM}$ PUT & 0.001 & 5.70 & $f-i$ & 8.31 & d-g & $12.52 \mathrm{bc}$ & $6.63 \mathrm{~B}$ \\
\hline $2 \mathrm{mM}$ PUT & 0.001 & 4.66 & h-k & 7.88 & d-g & $10.97 \mathrm{~cd}$ & $5.88 \mathrm{~B}$ \\
\hline $5 \%$ HPMC & 0.001 & 4.22 & $\mathrm{ijk}$ & 7.42 & $e-h$ & $9.33 \mathrm{de}$ & $5.24 \mathrm{BC}$ \\
\hline $1 \mathrm{mM}$ PUT incorporated with 5\% HPMC & 0.001 & 2.52 & $\mathrm{jkl}$ & 5.39 & $g-j$ & 8.62 def & $4.13 \mathrm{C}$ \\
\hline $2 \mathrm{mM}$ PUT incorporated with 5\% HPMC & 0.001 & 2.06 & $\mathrm{kl}$ & 5.79 & $f-i$ & $7.92 \mathrm{~d}-\mathrm{g}$ & $3.94 \mathrm{C}$ \\
\hline Means & $0.00 \mathrm{D}$ & 4.69 & $\mathrm{C}$ & 8.19 & $\mathrm{~B}$ & $11.34 \mathrm{~A}$ & \\
\hline
\end{tabular}

Means followed by the same letters within postharvest applications, storage periods and their interactions in each season are not significantly different at level $P \leq 0.05$ according to Duncan's multiple range test.

TABLE 2. Effect of postharvest applications of putrescine (PUT), hydroxypropyl methylcellulose (HPMC) and their incorporations on decay percentage of 'Maamoura' guava fruits during cold storage at $7 \pm 1^{\circ} \mathrm{C}$ and $90 \pm \mathbf{5 \%}$ RH

\begin{tabular}{|c|c|c|c|c|c|c|}
\hline \multirow{3}{*}{ Postharvest applications } & \multicolumn{5}{|c|}{ Storage period (days) } & \\
\hline & $\mathbf{0}$ & & 8 & 16 & 24 & \multirow[t]{2}{*}{ Means } \\
\hline & \multicolumn{5}{|c|}{ Season 2016} & \\
\hline Distilled water (control) & $0.00 \mathrm{e}$ & 14.29 & b-e & $28.57 \mathrm{~b}$ & $52.38 \mathrm{a}$ & $23.81 \mathrm{~A}$ \\
\hline $1 \mathrm{mM}$ PUT & $0.00 \mathrm{e}$ & 4.76 & de & $19.05 \mathrm{bcd}$ & $28.57 \mathrm{~b}$ & $13.10 \mathrm{~B}$ \\
\hline $2 \mathrm{mM}$ PUT & $0.00 \mathrm{e}$ & 0.00 & $\mathrm{e}$ & $14.29 \mathrm{~b}-\mathrm{e}$ & $23.81 \mathrm{bc}$ & $9.52 \mathrm{BC}$ \\
\hline $5 \%$ HPMC & $0.00 \mathrm{e}$ & 0.00 & $\mathrm{e}$ & 9.52 cde & $19.05 \mathrm{bcd}$ & $7.14 \mathrm{BC}$ \\
\hline $1 \mathrm{mM}$ PUT incorporated with 5\% HPMC & $0.00 \mathrm{e}$ & 0.00 & e & $0.00 \mathrm{e}$ & $14.29 \mathrm{~b}-\mathrm{e}$ & $3.57 \mathrm{C}$ \\
\hline $2 \mathrm{mM}$ PUT incorporated with 5\% HPMC & $0.00 \mathrm{e}$ & 0.00 & $\mathrm{e}$ & $0.00 \mathrm{e}$ & 9.52 cde & $2.38 \mathrm{C}$ \\
\hline \multirow[t]{2}{*}{ Means } & $0.00 \mathrm{C}$ & 3.17 & $\mathrm{C}$ & $11.90 \mathrm{~B}$ & $24.60 \mathrm{~A}$ & \\
\hline & \multicolumn{5}{|c|}{ Season 2017} & \\
\hline Distilled water (control) & $0.00 \mathrm{e}$ & 9.52 & de & $28.57 \mathrm{bc}$ & $59.24 \mathrm{a}$ & $24.33 \mathrm{~A}$ \\
\hline $1 \mathrm{mM}$ PUT & $0.00 \mathrm{e}$ & 4.76 & e & $23.81 \mathrm{bcd}$ & $33.33 \mathrm{~b}$ & $15.48 \mathrm{~B}$ \\
\hline $2 \mathrm{mM}$ PUT & $0.00 \mathrm{e}$ & 0.00 & $\mathrm{e}$ & 14.29 cde & $28.57 \mathrm{bc}$ & $10.71 \mathrm{BC}$ \\
\hline $5 \%$ HPMC & $0.00 \mathrm{e}$ & 0.00 & e & $9.52 \mathrm{de}$ & $23.81 \mathrm{bcd}$ & $8.33 \mathrm{BC}$ \\
\hline $1 \mathrm{mM}$ PUT incorporated with 5\% HPMC & $0.00 \mathrm{e}$ & 0.00 & $\mathrm{e}$ & $0.00 \mathrm{e}$ & 14.29 cde & $3.57 \mathrm{C}$ \\
\hline 2 mM PUT incorporated with 5\% HPMC & $0.00 \mathrm{e}$ & 0.00 & $\mathrm{e}$ & $0.00 \mathrm{e}$ & $9.52 \mathrm{de}$ & $2.38 \mathrm{C}$ \\
\hline Means & $0.00 \mathrm{C}$ & 2.38 & $\mathrm{C}$ & $12.70 \mathrm{~B}$ & $28.13 \mathrm{~A}$ & \\
\hline
\end{tabular}

Means followed by the same letters within postharvest applications, storage periods and their interactions in each season are not significantly different at level $P \leq 0.05$ according to Duncan's multiple range test. 
TABLE 3. Effect of postharvest applications of putrescine (PUT), hydroxypropyl methylcellulose (HPMC) and their incorporations on marketable percentage of 'Maamoura' guava fruits during cold storage at $7 \pm 1^{\circ} \mathrm{C}$ and $90 \pm 5 \% \mathrm{RH}$

\begin{tabular}{|c|c|c|c|c|c|}
\hline \multirow{3}{*}{ Postharvest applications } & \multicolumn{4}{|c|}{ Storage period (days) } & \multirow{3}{*}{ Means } \\
\hline & $\mathbf{0}$ & 8 & 16 & 24 & \\
\hline & \multicolumn{4}{|c|}{ Season 2016} & \\
\hline Distilled water (control) & $100.00 \mathrm{a}$ & $81.50 \mathrm{~b}-\mathrm{e}$ & $57.92 \mathrm{~g}$ & $28.55 \mathrm{~h}$ & $66.99 \mathrm{C}$ \\
\hline $1 \mathrm{mM}$ PUT & $100.00 \mathrm{a}$ & $89.76 \mathrm{abc}$ & $70.04 \mathrm{~d}-\mathrm{g}$ & $62.91 \mathrm{fg}$ & $80.68 \mathrm{~B}$ \\
\hline $2 \mathrm{mM}$ PUT & $100.00 \mathrm{a}$ & $95.59 \mathrm{ab}$ & 80.72 b-e & 66.76 efg & $85.77 \mathrm{AB}$ \\
\hline $5 \% \mathrm{HPMC}$ & $100.00 \mathrm{a}$ & $95.88 \mathrm{ab}$ & 85.80 a-d & $70.88 \mathrm{~d}-\mathrm{g}$ & $88.14 \mathrm{AB}$ \\
\hline $1 \mathrm{mM}$ PUT incorporated with 5\% HPMC & $100.00 \mathrm{a}$ & $96.54 \mathrm{ab}$ & $94.25 \mathrm{ab}$ & $76.78 \mathrm{c}-\mathrm{f}$ & $91.89 \mathrm{~A}$ \\
\hline 2 mM PUT incorporated with 5\% HPMC & $100.00 \mathrm{a}$ & $96.80 \mathrm{ab}$ & $94.49 \mathrm{ab}$ & $80.61 \mathrm{~b}-\mathrm{e}$ & $92.98 \mathrm{~A}$ \\
\hline \multirow[t]{2}{*}{ Means } & $100.00 \mathrm{~A}$ & $92.68 \mathrm{~B}$ & $80.53 \mathrm{C}$ & $64.41 \mathrm{D}$ & \\
\hline & \multicolumn{4}{|c|}{ Season 2017} & \\
\hline Distilled water (control) & $100.00 \mathrm{a}$ & $82.14 \mathrm{abc}$ & $52.14 \mathrm{e}$ & $24.19 \mathrm{f}$ & $64.62 \mathrm{C}$ \\
\hline $1 \mathrm{mM}$ PUT & $100.00 \mathrm{a}$ & $88.69 \mathrm{ab}$ & $66.41 \mathrm{cde}$ & $54.75 \mathrm{e}$ & $77.46 \mathrm{~B}$ \\
\hline $2 \mathrm{mM}$ PUT & $100.00 \mathrm{a}$ & $95.34 \mathrm{ab}$ & $77.24 \mathrm{bcd}$ & $60.37 \mathrm{de}$ & $83.24 \mathrm{~B}$ \\
\hline $5 \%$ HPMC & $100.00 \mathrm{a}$ & $95.78 \mathrm{ab}$ & $82.80 \mathrm{abc}$ & 66.63 cde & $86.30 \mathrm{AB}$ \\
\hline $1 \mathrm{mM}$ PUT incorporated with $5 \%$ HPMC & $100.00 \mathrm{a}$ & $97.48 \mathrm{ab}$ & $94.61 \mathrm{ab}$ & $78.10 \mathrm{bcd}$ & $92.55 \mathrm{~A}$ \\
\hline 2 mM PUT incorporated with 5\% HPMC & $100.00 \mathrm{a}$ & $97.94 \mathrm{ab}$ & $94.21 \mathrm{ab}$ & $82.61 \mathrm{abc}$ & $93.69 \mathrm{~A}$ \\
\hline Means & $100.00 \mathrm{~A}$ & $92.90 \mathrm{~A}$ & $77.90 \mathrm{~B}$ & $61.11 \mathrm{C}$ & \\
\hline
\end{tabular}

Means followed by the same letters within postharvest applications, storage periods and their interactions in each season are not significantly different at level $P \leq 0.05$ according to Duncan's multiple range test.

In addition, edible coatings restrict the air exchange, which reduce the surface permeability of fruits to oxygen and carbon dioxide leading to modification of internal gas composition, resulting in reduction of oxidative metabolism and increasing the shelf life of fruits (Dhall, 2013). Furthermore, coating has the ability to prevent the growth of fungi in wide horticultural produces (Tripathi \& Dubey, 2004).

The application of HPMC coating on guava fruits provides a partial barrier to movement of water, thus reducing moisture loss from fruit surface and establishes a modified atmosphere around the fruits, thus slowing down respiration and senescence processes (Baldwin et al., 1999, Olivas et al., 2008 and Dhall, 2013).

The lower weight loss and decay incidence in PUT, HPMC and their incorporations treated 'Maamoura' guava fruits could be attributed to stabilization and consolidation of both cell integrity and permeability of the tissues. In addition, these applications can reduce the exchange of gases between guava fruits and the environment by the accumulation of carbon dioxide in fruits and a low availability of oxygen for respiration and subsequently the inhibition of respiratory enzymes (Valero et al., 1998, Valencia-Chamorro et al., 2009 and Barman et al., 2011). Thus, these applications especially $2 \mathrm{mM}$ PUT incorporated with $5 \%$ HPMC reduced fruit loss in weight and controlled decay incidence as well as increased marketable percentage by delaying ripening and senescence processes of guava fruits as documented by Fagundes et al. (2014) and Razzaq et al. (2014).

Higher rates of weight loss and decay incidence were observed in control fruit during cold storage. These changes are associated with acceleration of senescence process (Woods, 1990), which were significantly suppressed by exogenous treatments of PUT and HPMC especially their incorporations (NavarroTarazaga et al., 2008 and Razzaq et al., 2014).

The above findings are in agreement with Valero et al. (1998) in lemons, MartínezRomero et al. (2000) in peaches, MartínezRomero et al. (2002) and Khosroshahi \& Esna-Ashari (2007) in apricots, Serrano et al. (2003) in plums, Mirdehghan et al. (2007) in pomegranates and Malik \& Singh, (2005), Jawandha et al. (2012) and Razzaq et al. (2014) in mangoes. They reported that postharvest Egypt. J. Hort. Vol. 45, No. 2 (2018) 
application of PUT reduced weight loss and decay percentages during cold storage period. In addition, coated mandarins with HPMC lipid composite reduced fruit weight loss percentage and decay incidence during storage as compared uncoated fruits (Pérez-Gago et al., 2002 and Navarro-Tarazaga et al., 2008). Moreover, the application of HPMC reduced decay incidence and weight loss of 'Tommy Atkins' mangoes during storage at $10-15^{\circ} \mathrm{C}$ in comparison to control (Baldwin et al., 1999). Furthermore, HPMC lipid edible composite coatings containing food additives are effective in reducing weight loss and controlling decay incidence of 'Valencia' oranges (ValenciaChamorro et al., 2009), 'Clemenules' mandarins (Valencia-Chamorro et al., 2011) and tomatoes (Fagundes et al., 2014). Furthermore, treatment of 'Mridula' pomegranates with PUT alone or in combination with carnauba wax resist penetration of water vapour from the fruit and thus lowered fruit weight loss during 60 days of storage at $3^{\circ} \mathrm{C}$ and no decay was observed during storage (Barman et al., 2011).

Effect of postharvest applications of putrescine (PUT), hydroxypropyl methylcellulose (HPMC) and their combinations on visual appearance and firmness of 'Maamoura' guava fruits during cold storage

Fruit visual appearance and firmness changes during cold storage at $7^{\circ} \mathrm{C}$ of 'Maamoura' guavas are shown in Tables 4 and 5. Our data indicate that, gradual and significant decrease in fruit visual appearance and firmness values were observed with the advancement of cold storage period at $7^{\circ} \mathrm{C}$ in both seasons. These results indicated that, the minimum visual appearance score (5.89 \& 5.56) and flesh firmness $(24.52 \& 21.19 \mathrm{~N})$ in the first and second seasons, respectively were recorded at the end of cold storage period.

Our data reveal that, postharvest applications of PUT, HPMC and their combinations of 'Maamoura' guava fruits significantly induced higher visual appearance score and flesh firmness values as compared to untreated fruits (control). In addition, dipped 'Maamoura' guava fruits in 1 or $2 \mathrm{mM}$ of PUT incorporated with 5\% HPMC for five minutes were more effective in retarding the reduction in fruit visual appearance and firmness than individual applications and untreated fruits (control) in the two seasons.
Dipped 'Maamoura' guavas in $2 \mathrm{mM}$ of PUT combined with 5\% HPMC recorded the highest values of visual appearance score $(8.83 \& 8.83)$ and flesh firmness $(56.18 \& 47.89 \mathrm{~N})$ in 2016 and 2017 seasons, respectively. On contrary, untreated fruits (control) showed the lowest visual appearance score (6.33 \& 5.58) and firmness value $(25.29 \& 20.76 \mathrm{~N})$ in the first and second seasons, respectively.

As for the interaction effect, there was a significant interaction between postharvest applications and storage periods at $p \leq 0.05$ for fruit visual appearance and flesh firmness in both seasons in this work. The results indicate that, at the end of cold storage period ( 24 days), treated 'Maamoura' guava fruits with $2 \mathrm{mM}$ PUT plus $5 \%$ HPMC recorded the significant highest of fruit visual appearance score $(8.33 \& 8.33)$ and firmness $(40.70 \& 34.00 \mathrm{~N})$ in 2016 and 2017 seasons, respectively. On contrary, untreated fruits (control) recorded the significant lowest of fruit visual appearance score $(2.33 \& 2.00)$ and firmness $(2.45 \& 1.63 \mathrm{~N})$ in the first and second seasons, respectively.

Fruit firmness is extremely important in overall produce acceptance by the consumers. Guava fruits suffer a rapid loss of firmness after harvest, which contributes greatly to its short postharvest life and susceptibility to fungal contamination (Reyes \& Paul, 1995). The loss of fruit firmness starts with the conversion of insoluble protopectin into water soluble pectin by breakdown of the middle lamellae, which is intimately related to hydrolytic enzyme, so rigidity of cell walls would be reduced and leading to fruit softening (Payasi et al., 2009). The reduction flesh firmness of guavas with the progress of cold storage could be attributed to the increase in activities of cell wall hydrolysis enzymes and the degradation in cellular structures accompanied with the increases in ethylene production and respiration rate (Reyes \& Paul, 1995, Jain et al., 2003 and Mondal, 2005).

Polyamines strengthen the cell walls by cross linking to the carboxyl group of the pectic substances in the cell wall resulting in wall rigidity. This binding also suppresses cell wall degrading enzymes and ultimately reducing the rate of softening during storage (Valero et al. 2002, Mondal, 2005 and Razzaq et al., 2014). 
TABLE 4. Effect of postharvest applications of putrescine (PUT), hydroxypropyl methylcellulose (HPMC) and their incorporations on visual appearance score of 'Maamoura' guava fruits during cold storage at $7 \pm 1^{\circ} \mathrm{C}$ and $90 \pm 5 \% \mathrm{RH}$

\begin{tabular}{|c|c|c|c|c|c|c|c|c|c|}
\hline \multirow{4}{*}{$\begin{array}{l}\text { Postharvest applications } \\
\text { Distilled water (control) }\end{array}$} & \multicolumn{7}{|c|}{ Storage period (days) } & & \\
\hline & $\mathbf{0}$ & & 8 & & 16 & & 24 & \multirow{2}{*}{\multicolumn{2}{|c|}{ Means }} \\
\hline & \multicolumn{7}{|c|}{ Season 2016} & & \\
\hline & $9.00 \mathrm{a}$ & 7.67 & $a-d$ & 6.33 & def & 2.33 & $\mathrm{~g}$ & 6.33 & $\mathrm{D}$ \\
\hline $1 \mathrm{mM}$ PUT & $9.00 \mathrm{a}$ & 9.00 & $\mathrm{a}$ & 7.33 & bcd & 5.00 & $\mathrm{f}$ & 7.58 & $\mathrm{C}$ \\
\hline $2 \mathrm{mM}$ PUT & $9.00 \mathrm{a}$ & 9.00 & $\mathrm{a}$ & 8.00 & $a b c$ & 5.67 & ef & 7.92 & $\mathrm{BC}$ \\
\hline $5 \% \mathrm{HPMC}$ & $9.00 \mathrm{a}$ & 9.00 & $\mathrm{a}$ & 8.33 & $\mathrm{ab}$ & 6.67 & cde & 8.25 & $\mathrm{ABC}$ \\
\hline $1 \mathrm{mM}$ PUT incorporated with $5 \%$ HPMC & $9.00 \mathrm{a}$ & 9.00 & $\mathrm{a}$ & 9.00 & a & 7.33 & bcd & 8.58 & $\mathrm{AB}$ \\
\hline $2 \mathrm{mM}$ PUT incorporated with 5\% HPMC & $9.00 \mathrm{a}$ & 9.00 & $\mathrm{a}$ & 9.00 & $\mathrm{a}$ & 8.33 & $\mathrm{ab}$ & 8.83 & A \\
\hline \multirow[t]{2}{*}{ Means } & $9.00 \mathrm{~A}$ & 8.78 & A & 8.00 & $\mathrm{~B}$ & 5.89 & $\mathrm{C}$ & & \\
\hline & \multicolumn{7}{|c|}{ Season 2017} & & \\
\hline Distilled water (control) & $9.00 \mathrm{a}$ & 6.00 & $\mathrm{~cd}$ & 5.33 & de & 2.00 & $\mathrm{f}$ & 5.58 & $\mathrm{E}$ \\
\hline $1 \mathrm{mM}$ PUT & $9.00 \mathrm{a}$ & 9.00 & $\mathrm{a}$ & 7.00 & $\mathrm{bc}$ & 4.33 & $\mathrm{e}$ & 7.33 & $\mathrm{D}$ \\
\hline $2 \mathrm{mM}$ PUT & $9.00 \mathrm{a}$ & 9.00 & $\mathrm{a}$ & 7.67 & $\mathrm{ab}$ & 5.67 & $\mathrm{~d}$ & 7.83 & $\mathrm{CD}$ \\
\hline $5 \%$ HPMC & $9.00 \mathrm{a}$ & 9.00 & a & 8.00 & $\mathrm{ab}$ & 6.00 & $\mathrm{~cd}$ & 8.00 & $\mathrm{BC}$ \\
\hline $1 \mathrm{mM}$ PUT incorporated with $5 \%$ HPMC & $9.00 \mathrm{a}$ & 9.00 & a & 9.00 & $\mathrm{a}$ & 7.00 & $\mathrm{bc}$ & 8.50 & $\mathrm{AB}$ \\
\hline $2 \mathrm{mM}$ PUT incorporated with $5 \%$ HPMC & $9.00 \mathrm{a}$ & 9.00 & a & 9.00 & a & 8.33 & a & 8.83 & A \\
\hline Means & $9.00 \mathrm{~A}$ & 8.50 & $\mathrm{~B}$ & 7.67 & $\mathrm{C}$ & 5.56 & $\mathrm{D}$ & & \\
\hline
\end{tabular}

Means followed by the same letters within postharvest applications, storage periods and their interactions in each season are not significantly different at level $P \leq 0.05$ according to Duncan's multiple range test.

TABLE 5. Effect of postharvest applications of putrescine (PUT), hydroxypropyl methylcellulose (HPMC) and their incorporations on firmness $(\mathrm{N})$ of 'Maamoura' guava fruits during cold storage at $7 \pm 1^{\circ} \mathrm{C}$ and $\mathbf{9 0} \pm \mathbf{5} \% \mathbf{R H}$

\begin{tabular}{|c|c|c|c|c|c|c|c|}
\hline \multirow{3}{*}{ Postharvest applications } & \multicolumn{6}{|c|}{ Storage period (days) } & \multirow{3}{*}{ Means } \\
\hline & $\mathbf{0}$ & & 8 & 16 & & 24 & \\
\hline & \multicolumn{6}{|c|}{ Season 2016} & \\
\hline Distilled water (control) & $67.67 \mathrm{a}$ & 21.90 & hij & $9.15 \mathrm{kl}$ & 2.45 & 1 & $25.29 \mathrm{E}$ \\
\hline $1 \mathrm{mM}$ PUT & $67.67 \mathrm{a}$ & 48.22 & cde & $32.04 \mathrm{fgh}$ & 17.00 & $\mathrm{jk}$ & $41.23 \mathrm{D}$ \\
\hline $2 \mathrm{mM}$ PUT & $67.67 \mathrm{a}$ & 55.08 & $a b c$ & 36.94 efg & 19.94 & $\mathrm{ijk}$ & $44.91 \mathrm{CD}$ \\
\hline 5\% HPMC & $67.67 \mathrm{a}$ & 57.37 & $a b c$ & $42.50 \mathrm{def}$ & 29.75 & ghi & $49.32 \mathrm{BC}$ \\
\hline $1 \mathrm{mM}$ PUT incorporated with 5\% HPMC & $67.67 \mathrm{a}$ & 61.29 & $a b$ & 46.42 cde & 37.27 & efg & $53.16 \mathrm{AB}$ \\
\hline 2 mM PUT incorporated with 5\% HPMC & $67.67 \mathrm{a}$ & 64.23 & $a b$ & $52.14 \mathrm{bcd}$ & 40.70 & d-g & $56.18 \mathrm{~A}$ \\
\hline \multirow[t]{2}{*}{ Means } & $67.67 \mathrm{~A}$ & 51.35 & $\mathrm{~B}$ & $36.53 \mathrm{C}$ & 24.52 & $\mathrm{D}$ & \\
\hline & \multicolumn{6}{|c|}{ Season 2017} & \\
\hline Distilled water (control) & 58.84 a & 15.04 & $\mathrm{jk}$ & $7.52 \mathrm{kl}$ & 1.63 & 1 & $20.76 \mathrm{E}$ \\
\hline $1 \mathrm{mM}$ PUT & 58.84 a & 42.82 & $c-f$ & $30.56 \mathrm{gh}$ & 15.69 & $\mathrm{jk}$ & $36.98 \mathrm{D}$ \\
\hline $2 \mathrm{mM}$ PUT & 58.84 a & 44.46 & $b-f$ & 34.32 e-h & 18.63 & ij & $39.06 \mathrm{CD}$ \\
\hline $5 \%$ HPMC & $58.84 \mathrm{a}$ & 46.09 & bcd & $37.27 \mathrm{~d}-\mathrm{g}$ & 26.15 & hi & $42.09 \mathrm{BC}$ \\
\hline 1 mM PUT incorporated with $5 \%$ HPMC & $58.84 \mathrm{a}$ & 49.69 & $\mathrm{abc}$ & $40.21 \mathrm{c}-\mathrm{g}$ & 31.05 & gh & $44.95 \mathrm{AB}$ \\
\hline 2 mM PUT incorporated with $5 \%$ HPMC & $58.84 \mathrm{a}$ & 53.94 & $\mathrm{ab}$ & $44.78 \mathrm{~b}-\mathrm{e}$ & 34.00 & fgh & $47.89 \mathrm{~A}$ \\
\hline Means & $58.84 \mathrm{~A}$ & 42.01 & $\mathrm{~B}$ & $32.44 \mathrm{C}$ & 21.19 & $\mathrm{D}$ & \\
\hline
\end{tabular}

Means followed by the same letters within postharvest applications, storage periods and their interactions in each season are not significantly different at level $P \leq 0.05$ according to Duncan's multiple range test. 
Edible coatings influence fruit quality by restricting oxygen from entering, thus modifying the internal gas composition and reducing oxidative metabolism (Olivas et al., 2008 and Dhall, 2013). Treatment of 'Mridula' pomegranate fruits with $2 \mathrm{mM}$ PUT alone or in combination with carnauba wax lowered fruit respiration and ethylene production rates as well as blocking the access to cell wall degrading enzymes, thereby reducing the rate of softening during cold storage (Barman et al., 2011). In addition, the effect of coatings on the maintenance of fruit firmness was related to their ability to control weight loss (NavarroTarazaga et al., 2008).

The reduction in fruit softening by the applications of PUT, HPMC and their combinations may be ascribed to their bonds with pectin resulting in rigidity, which stabilize cell walls by blocks the access of cell wall degrading enzymes as reported by Valero et al. (2002) and Razzaq et al. (2014). Thus, these applications reduced 'Maamoura' guava fruits softening and maintained visual appearance of fruits during cold storage. Similarly, treatment with exogenous of PUT has been reported to increase fruit firmness in lemons (Valero et al., 1998), peaches (Martínez-Romero et al., 2000), apricots (Martínez-Romero et al., 2002 and Khosroshahi \& Esna-Ashari, 2007), plums (Serrano et al., 2003 and Khan et al., 2007), pomegranates (Mirdehghan et al. 2007) and mangoes (Razzaq et al., 2014). In addition, the application of HPMC improved the visual appearance for stored 'Tommy Atkins' mangoes by imparting shine of fruits in comparison to uncoated fruits (Baldwin et al., 1999). Moreover, HPMC lipid edible composite coatings containing food additives were effective in maintaining firmness of 'Valencia' oranges (Valencia-Chamorro et al., 2009), mandarins (Navarro-Tarazaga et al., 2008 and Valencia-Chamorro et al., 2011) and tomatoes (Fagundes et al., 2014).

In addition, severe decrease in firmness of untreated 'Maamoura' guava fruits (control) was accompanied with the increases in activities of cell wall hydrolysis enzymes and the degradation in cellular structures because of the high rates of ethylene production, respiration and other metabolic activities (Mondal, 2005, Barman et al., 2011 and Razzaq et al., 2014).

Egypt. J. Hort. Vol. 45, No.2 (2018)
Effect of postharvest applications of putrescine (PUT), hydroxypropyl methylcellulose (HPMC) and their incorporations on total chlorophyll and total carotenoids contents of 'Maamoura' guava fruits during cold storage

Data in Tables 6 and 7 show that, changes in colour of 'Maamoura' guavas from yellowish green to yellow increased with the progress of cold storage period at $7^{\circ} \mathrm{C}$ in the two seasons. In this concern, the minimal total chlorophyll content $(6.93 \& 4.35 \mathrm{mg} / 100 \mathrm{~g} \mathrm{fw})$ in the first and second seasons, respectively was noticed at the end of cold storage period. Moreover, maximal 'Maamoura' guava fruits content of total carotenoids was observed after 16 days of cold storage period $(5.02 \& 5.38 \mathrm{mg} / 100 \mathrm{~g} \mathrm{fw})$ in the first and second seasons, respectively. After that, total carotenoids decreased till the end of cold storage and the values reached of $4.11 \& 5.36 \mathrm{mg} / 100 \mathrm{~g} \mathrm{fw}$ in the 2016 and 2017 seasons, respectively. However, this decrease was significant in the first season and nonsignificant in the second season.

Data tabulated in Tables 6 and 7 demonstrate that, postharvest applications of PUT, HPMC and their combinations delayed colour development of 'Maamoura' guava fruits during cold storage period at $7^{\circ} \mathrm{C}$ and significantly retained total chlorophyll content. Interestingly, incorporated treatments of 'Maamoura' guava fruits were superior in constricting the changing rate of colour than individual applications and untreated fruits (control) in both seasons by delayed chlorophyll breakdown.

On the average fruits dipped in $2 \mathrm{mM}$ PUT combined with 5\% HPMC showed maximum retention in total chlorophyll content (13.09 \& $11.25 \mathrm{mg} / 100 \mathrm{~g} \mathrm{fw}$ ) and minimum total carotenoids content $(3.21 \& 3.66 \mathrm{mg} / 100 \mathrm{~g} \mathrm{fw})$ in 2016 and 2017 seasons, respectively followed by treated fruits by $1 \mathrm{mM}$ PUT incorporated with 5\% HPMC in the two seasons. On the other hand, untreated fruits (control) recorded the minimum total chlorophyll content (8.27 \& $6.03 \mathrm{mg} / 100 \mathrm{~g} \mathrm{fw}$ ) and total carotenoids content reached of $3.22 \& 3.78 \mathrm{mg} / 100 \mathrm{~g}$ fw in the first and second seasons, respectively. 
TABLE 6. Effect of postharvest applications of putrescine (PUT), hydroxypropyl methylcellulose (HPMC) and their incorporations on total chlorophyll content $(\mathrm{mg} / 100 \mathrm{~g}$ fw) of 'Maamoura' guava fruits during cold storage at $7 \pm 1^{\circ} \mathrm{C}$ and $90 \pm 5 \% \mathrm{RH}$

\begin{tabular}{|c|c|c|c|c|c|c|}
\hline \multirow{3}{*}{ Postharvest applications } & \multicolumn{5}{|c|}{ Storage period (days) } & \\
\hline & $\mathbf{0}$ & 8 & 16 & & 24 & \multirow[t]{2}{*}{ Means } \\
\hline & \multicolumn{5}{|c|}{ Season 2016} & \\
\hline Distilled water (control) & $16.54 \mathrm{a}$ & $6.84 \mathrm{ij}$ & $5.95 \mathrm{j}$ & 3.75 & $\mathrm{k}$ & $8.27 \mathrm{D}$ \\
\hline $1 \mathrm{mM}$ PUT & $16.54 \mathrm{a}$ & $9.43 \mathrm{fgh}$ & 7.57 hij & 6.40 & $\mathrm{j}$ & $9.98 \mathrm{C}$ \\
\hline $2 \mathrm{mM}$ PUT & $16.54 \mathrm{a}$ & $10.23 \mathrm{efg}$ & 8.56 ghi & 6.89 & $\mathrm{ij}$ & $10.55 \mathrm{BC}$ \\
\hline $5 \% \mathrm{HPMC}$ & $16.54 \mathrm{a}$ & $11.12 \mathrm{def}$ & 8.73 ghi & 7.54 & hij & $10.98 \mathrm{~B}$ \\
\hline $1 \mathrm{mM}$ PUT incorporated with 5\% HPMC & $16.54 \mathrm{a}$ & $13.38 \mathrm{bc}$ & $11.37 \mathrm{de}$ & 8.33 & ghi & $12.41 \mathrm{~A}$ \\
\hline $2 \mathrm{mM}$ PUT incorporated with $5 \%$ HPMC & $16.54 \mathrm{a}$ & $14.63 \mathrm{ab}$ & $12.49 \mathrm{~cd}$ & 8.69 & ghi & $13.09 \mathrm{~A}$ \\
\hline \multirow[t]{2}{*}{ Means } & $16.54 \mathrm{~A}$ & $10.94 \mathrm{~B}$ & $9.11 \mathrm{C}$ & 6.93 & $\mathrm{D}$ & \\
\hline & \multicolumn{5}{|c|}{ Season 2017} & \\
\hline Distilled water (control) & $15.41 \mathrm{a}$ & 4.55 hij & $2.92 \mathrm{jk}$ & 1.23 & $\mathrm{k}$ & $6.03 \mathrm{C}$ \\
\hline $1 \mathrm{mM}$ PUT & $15.41 \mathrm{a}$ & $6.94 \mathrm{e}-\mathrm{h}$ & $4.82 \mathrm{~g}-\mathrm{j}$ & 2.82 & $\mathrm{jk}$ & $7.50 \mathrm{~B}$ \\
\hline $2 \mathrm{mM}$ PUT & $15.41 \mathrm{a}$ & $7.68 \mathrm{c}-\mathrm{g}$ & $5.71 \mathrm{f}-\mathrm{j}$ & 3.54 & $\mathrm{ijk}$ & $8.09 \mathrm{~B}$ \\
\hline $5 \% \mathrm{HPMC}$ & $15.41 \mathrm{a}$ & $8.71 \mathrm{c}-\mathrm{f}$ & 6.14 e-i & 4.34 & hij & $8.65 \mathrm{~B}$ \\
\hline $1 \mathrm{mM}$ PUT incorporated with 5\% HPMC & $15.41 \mathrm{a}$ & $10.43 \mathrm{bc}$ & 9.17 b-e & 6.90 & $\mathrm{e}-\mathrm{h}$ & $10.48 \mathrm{~A}$ \\
\hline $2 \mathrm{mM}$ PUT incorporated with 5\% HPMC & $15.41 \mathrm{a}$ & $12.03 \mathrm{~b}$ & $10.27 \mathrm{bcd}$ & 7.30 & d-h & $11.25 \mathrm{~A}$ \\
\hline Means & $15.41 \mathrm{~A}$ & $8.39 \mathrm{~B}$ & $6.50 \mathrm{C}$ & 4.35 & $\mathrm{D}$ & \\
\hline
\end{tabular}

Means followed by the same letters within postharvest applications, storage periods and their interactions in each season are not significantly different at level $P \leq 0.05$ according to Duncan's multiple range test.

TABLE 7. Effect of postharvest applications of putrescine (PUT), hydroxypropyl methylcellulose (HPMC) and their incorporations on total carotenoids content $(\mathrm{mg} / 100 \mathrm{~g} f w)$ of 'Maamoura' guava fruits during cold storage at $7 \pm 1^{\circ} \mathrm{C}$ and $90 \pm 5 \% \mathrm{RH}$

\begin{tabular}{|c|c|c|c|c|c|c|c|c|c|}
\hline \multirow{3}{*}{ Postharvest applications } & \multicolumn{7}{|c|}{ Storage period (days) } & \multirow{3}{*}{\multicolumn{2}{|c|}{ Means }} \\
\hline & $\mathbf{0}$ & & 8 & & 16 & & 24 & & \\
\hline & \multicolumn{7}{|c|}{ Season 2016} & & \\
\hline Distilled water (control) & $1.32 \mathrm{i}$ & 4.82 & bcd & 3.84 & $c-f$ & 2.91 & fgh & 3.22 & $\mathrm{~B}$ \\
\hline $1 \mathrm{mM}$ PUT & $1.32 \mathrm{i}$ & 4.73 & bcd & 6.61 & $\mathrm{a}$ & 3.64 & d-g & 4.07 & A \\
\hline $2 \mathrm{mM}$ PUT & $1.32 \mathrm{i}$ & 3.91 & $c-f$ & 5.68 & $a b$ & 3.75 & d-g & 3.66 & $\mathrm{AB}$ \\
\hline $5 \%$ HPMC & $1.32 \mathrm{i}$ & 3.34 & e-h & 5.17 & $\mathrm{bc}$ & 4.53 & $b-e$ & 3.59 & $\mathrm{AB}$ \\
\hline $1 \mathrm{mM}$ PUT incorporated with 5\% HPMC & $1.32 \mathrm{i}$ & 2.48 & ghi & 4.43 & b-e & 4.95 & bed & 3.29 & $\mathrm{~B}$ \\
\hline $2 \mathrm{mM}$ PUT incorporated with 5\% HPMC & $1.32 \mathrm{i}$ & 2.25 & hi & 4.39 & b-e & 4.89 & bed & 3.21 & $\mathrm{~B}$ \\
\hline \multirow[t]{2}{*}{ Means } & $1.32 \mathrm{D}$ & 3.59 & $\mathrm{C}$ & 5.02 & $\mathrm{~A}$ & 4.11 & $\mathrm{~B}$ & & \\
\hline & \multicolumn{7}{|c|}{$\begin{array}{cc}5.59 \quad \mathrm{C} & 5.02 \text { A } \\
& \text { Season } 2017\end{array}$} & & \\
\hline Distilled water (control) & $1.90 \mathrm{~g}$ & 5.79 & abc & 4.31 & b-f & 3.11 & d-g & 3.78 & $\mathrm{AB}$ \\
\hline $1 \mathrm{mM}$ PUT & $1.90 \mathrm{~g}$ & 4.88 & $a-d$ & 6.65 & a & 5.41 & abc & 4.71 & A \\
\hline $2 \mathrm{mM}$ PUT & $1.90 \mathrm{~g}$ & 4.74 & a-e & 6.57 & a & 5.72 & $a b c$ & 4.73 & A \\
\hline $5 \%$ HPMC & $1.90 \mathrm{~g}$ & 3.92 & $\mathrm{c}-\mathrm{g}$ & 6.19 & $\mathrm{ab}$ & 5.92 & $a b c$ & 4.48 & $\mathrm{AB}$ \\
\hline $1 \mathrm{mM}$ PUT incorporated with 5\% HPMC & $1.90 \mathrm{~g}$ & 2.75 & efg & 4.34 & $b-f$ & 6.00 & $\mathrm{abc}$ & 3.75 & $\mathrm{AB}$ \\
\hline 2 mM PUT incorporated with 5\% HPMC & $1.90 \mathrm{~g}$ & 2.55 & fg & 4.20 & $b-f$ & 5.98 & $a b c$ & 3.66 & $\mathrm{~B}$ \\
\hline Means & $1.90 \mathrm{C}$ & 4.10 & $\mathrm{~B}$ & 5.38 & A & 5.36 & A & & \\
\hline
\end{tabular}

Means followed by the same letters within postharvest applications, storage periods and their interactions in each season are not significantly different at level $P \leq 0.05$ according to Duncan's multiple range test. 
Referring to the interaction effect, significant differences were found between postharvest applications and storage periods at $p \leq 0.05$ for total chlorophyll and total carotenoids of 'Maamoura' guava fruits in the two seasons under this experiment. Our results indicate that, at the end of cold storage period (24 days), treated 'Maamoura' guava fruits with $2 \mathrm{mM}$ PUT plus $5 \%$ HPMC recorded the significant highest of total chlorophyll content $(8.69 \& 7.30 \mathrm{mg} / 100$ $\mathrm{g}$ fw) followed by $1 \mathrm{mM}$ PUT plus 5\% HPMC (8.33 \& $6.90 \mathrm{mg} / 100 \mathrm{~g} \mathrm{fw})$ in 2016 and 2017 seasons, respectively. On contrary, untreated fruits (control) recorded the significant lowest of total chlorophyll content $(3.75 \& 1.23 \mathrm{mg} / 100 \mathrm{~g}$ fw) in the first and second seasons, respectively. On the other side, the highest total carotenoids content of untreated fruits (control) was observed at eight days of cold storage at $7^{\circ} \mathrm{C}(4.82 \& 5.79$ $\mathrm{mg} / 100 \mathrm{~g} \mathrm{fw}$ ) and then decreased till the end of cold storage period and the values reached of 2.91 \& $3.11 \mathrm{mg} / 100 \mathrm{~g}$ fw in the two seasons. While, the highest total carotenoids was recorded eight days later by treated with individual treatments in both seasons. Whereas, combined treatments showed a gradual increase in total carotenoids till the end of cold storage period in the two seasons under this experiment (Table 7). However, at the end of cold storage period (24 days), the total carotenoids content of treated 'Maamoura' guava fruits with 2 $\mathrm{mM}$ PUT plus 5\% HPMC reached of $4.89 \& 5.98$ $\mathrm{mg} / 100 \mathrm{~g}$ fw.

The loss of chlorophyll content during cold storage could be attributed to the breakdown of the chlorophyll structure and increases in chlorophyllase enzyme activity of pigments. After chlorophyll degradation, yellow carotenoid pigments become visible (Wills et al., 1998).

In this experiment, the higher colour retention of 'Maamoura' guava fruits treated with PUT, HPMC and their combinations specially $2 \mathrm{mM}$ PUT incorporated with 5\% HPMC could be attributed to the increasing level of endogenous PUT, reduces the rates of respiration and ethylene production and consequently delays ripening and senescence processes (Mondal, 2005). Thus, these applications slowed the change of colour from yellowish green to yellow by the reduction of chlorophyll degrading enzyme activities and climacteric rise in respiration and ethylene production during cold storage period (Wills et al., 1998, Mondal, 2005 and Barman et al., 2011).

Egypt. J. Hort. Vol. 45, No.2 (2018)
Delaying of fruit skin colour degradation when treated with PUT has been reported for apricots (Martínez-Romero et al., 2002), plums (Serrano et al., 2003), lemons (Valero et al., 1998) and mangoes (Malik \& Singh, 2005). In addition, inhibition of chlorophyll breakdown as a result of coating applications was observed in previous studies on various horticultural products (Olivas et al., 2008 and Dhall, 2013). The application of HPMC coating reduced the development of colour and delayed fruit ripening in 'Kent', 'Tommy Atkins' and 'Lirfa' mangoes as compared to uncoated fruits (Hoa et al., 2002). Moreover, 'Mridula' pomegranate fruit treated with PUT alone or plus carnauba wax delayed colour development during cold storage period for 60 days at $3^{\circ} \mathrm{C}$ plus 3 days at $20^{\circ} \mathrm{C}$ (Barman et al., 2011).

In addition, severe increase in colour development of untreated 'Maamoura' guava fruits (control) was accompanied with the increases in ethylene production and respiration rates, thus hastening ripening and senescence processes and consequently increasing chlorophyll breakdown (Hoa et al., 2002 and Mondal, 2005). In this study, untreated 'Maamoura' guavas reached full yellow colour within eight days. Furthermore, the decline in total carotenoids content of individual treatments and untreated fruits (control) at later stage of cold storage period might be due to the fruit senescence as documented by Mondal (2005).

Effect of postharvest applications of putrescine (PUT), hydroxypropyl methylcellulose (HPMC) and their combinations on Ascorbic acid (AsA), total soluble solids (TSS), titratable acidity (TA) contents and TSS/TA ratio of 'Maamoura' guava fruits during cold storage

Data in Tables 8 and 10 show a declining trend of 'Maamoura' guavas contents of AsA and TA observed with the advancement of cold storage period at $7^{\circ} \mathrm{C}$ in both seasons. Our results in this experiment revealed that, the minimum 'Maamoura' guavas contents of AsA and TA were noticed at the end of cold storage period and the values reached of $65.61 \& 70.12$ $\mathrm{mg} / 100 \mathrm{ml}$ juice and $0.48 \& 0.42 \%$, respectively in the first and second seasons, respectively. In addition, 'Maamoura' guava fruits content of TSS significantly increased till 16 days of cold storage period at $7^{\circ} \mathrm{C}$ followed by a significant decrease till the end of the storage period in the two seasons 
(Table 9). While, TSS/TA ratio gradually and significantly increased with the progress of cold storage period in both seasons (Table 11). The highest fruits content of TSS was recorded at 16 days of cold storage period $\left(10.45 \& 10.58^{\circ}\right.$ Brix $)$ followed by a significant decrease till the end of the experiment and the values reached of 10.06 \& $10.07{ }^{\circ}$ Brix in the first and second seasons, respectively. Moreover, the highest TSS/TA ratio was recorded at the end of cold storage period and the values were $24.06 \& 25.86$ in 2016 and 2017 seasons, respectively.

Postharvest applications of PUT, HPMC and their combinations significantly decreased losses in 'Maamoura' guavas contents of AsA and TA as compared to untreated fruits (control) during cold storage period at $7^{\circ} \mathrm{C}$ in the two seasons. Moreover, combined treatments were more effective in maintaining AsA and TA contents of fruits as compared with individual treatment in both seasons. Dipped 'Maamoura' guava fruits in $2 \mathrm{mM}$ PUT incorporated with 5\% HPMC for five minutes significantly attained the highest contents of AsA (92.13 \& $101.67 \mathrm{mg} / 100 \mathrm{ml}$ juice) and TA $(0.94 \& 0.83 \%)$ in the first and second seasons, respectively. On contrary, the losses of AsA and TA contents were more rapid in untreated fruits (control) and recorded the lowest contents in AsA content $(72.04 \& 77.60 \mathrm{mg} / 100 \mathrm{ml}$ juice $)$ and TA (0.65 \& $0.61 \%)$ in 2016 and 2017 seasons.

In addition, statistical data tabulated in Tables 9 and 11 show that, postharvest applications PUT and HPMC slowed the increase of guavas contents of TSS and TSS/TA ratio in comparison to untreated fruits (control) during cold storage period at $7^{\circ} \mathrm{C}$ in both seasons. Moreover, dipped 'Maamoura' guavas in 1 or $2 \mathrm{mM}$ incorporated with 5\% HPMC for five minutes were more superior in this respect than individual treatment and untreated fruits (control) in the two seasons. However, treated fruits showed non-significant lower values on the average of fruits contents of TSS in comparison to untreated fruits (control), otherwise combined treatments that showed significant lower values in both seasons. These results indicated that, treated 'Maamoura' guava fruits with $2 \mathrm{mM}$ PUT plus 5\% HPMC for five minutes significantly attained the significant lowest values of TSS (8.46 \& $8.67{ }^{\circ}$ Brix) and TSS/TA ratio (9.53 \& 11.43) in 2016 and 2017 seasons, respectively followed by treated fruits with $1 \mathrm{mM}$ PUT plus 5\% HPMC. On contrary, untreated fruits (control) recorded the highest values of TSS (8.85 \& $9.00{ }^{\circ}$ Brix) and TSS/ TA ratio $(18.91 \& 20.70)$ in the first and second seasons, respectively.

The interaction effect between pre-storage treatments and storage periods showed significant difference interactions at $p \leq 0.05$ for 'Maamoura' guava fruits contents of AsA, TSS, TA and TSS/TA ratio in both seasons in the current investigation. Our results indicate that, at the end of cold storage period (24 days), treated 'Maamoura' guava fruits with $2 \mathrm{mM}$ PUT plus 5\% HPMC recorded the significant highest of AsA (80.91 \& $88.91 \mathrm{mg} / 100$ $\mathrm{ml}$ juice $)$ and TA $(0.77 \& 0.62 \%)$ in the first and second seasons, respectively. On contrary, untreated fruits (control) recorded the significant lowest of AsA (44.13 \& $48.11 \mathrm{mg} / 100 \mathrm{ml}$ juice) and TA $(0.30 \& 0.29 \%)$ in 2016 and 2017 seasons, respectively. On the other side, the highest TSS of all postharvest treatments and control was observed at 16 days of cold storage at $7^{\circ} \mathrm{C}$ and then decreased till the end of cold storage period in both seasons. At the end of cold storage period (24 days), TSS of treated 'Maamoura' guava fruits with 2 mM PUT plus 5\% HPMC reached of 10.13 $\& 10.33{ }^{\circ}$ Brix in the first and second seasons, respectively and in the same time recorded the significant lowest of TSS/TA ratio (13.46 \& 16.75) in 2016 and 2017 seasons, respectively. Whereas, at the same period, untreated fruits (control) recorded the significant lowest of TSS (9.60 \& $9.47{ }^{\circ}$ Brix) in 2016 and 2017 seasons, respectively as well as recorded the significant highest of TSS/TA ratio (33.25\& 33.62) in the first and second seasons, respectively.

The loss of ascorbic acid content of guavas during cold storage period might be due to a rapid conversion of L-ascorbic acid into dehydroascorbic acid in the presence of oxidizing enzymes like ascorbic acid oxidase and ascorbate peroxidase (Davey et al., 2000). Moreover, TA is directly related to the concentration of organic acids present in the fruit. Citric acid is the major organic acid in guava fruits, which is an important parameter in maintaining the quality of fruits and rapid reduction in acidity hastens senescence of fruits (Jain et al., 2003). The progressive decline of guavas content in TA with the advancement of storage period might be due to utilization of organic acids in respiration process and conversion of acids into salts and sugars by the enzymes (Jain et al., 2003). On the other hand, the increase in guavas content in TSS with prolonging of storage period could be attributed to the hydrolysis of

Egypt. J. Hort. Vol. 45, No. 2 (2018) 
starch into sugars and an increase in water soluble galacturonic acids from the degradation of pectic substances by hydrolytic enzymes (Jain et al., 2003). Whereas, slight decline of fruits content in TSS at the end of storage period might be due to utilization of soluble solids in respiratory processes (Jain et al., 2003).

Exogenous application of polyamines have been reported to increase the level of endogenous polyamines and reduce the rates of respiration and ethylene production and consequently delaying ripening and senescence processes (Valero et al. 2002, Serrano et al., 2003 and Barman et al., 2011).

Higher TA and AsA contents of 'Maamoura' guavas by treatments of PUT, HPMC and their combinations might be due to their effect in reducing respiration rate and delaying the progress of the ripening and senescence processes of fruits during cold storage period (Barman et al., 2011 and Razzaq et al., 2014). In addition, an increase of AsA content by these treatments might be ascribed to the suppression of ascorbate oxidase activity and consequently slowing down the conversion of ascorbic acid into dehydro ascorbic acid (Davey et al., 2000). This positive effect might be attributed to the increased levels of endogenous polyamines in pulp of fruits (Martínez-Romero et al., 2000, Martínez-Romero et al., 2002 and Serrano et al., 2003). Moreover, the lowest fruit contents in TSS and TSS/TA ratio in these treatments were ascribed to a reduction in the respiration of the fruits and suppression the ethylene production, which consequently affected the acid and sugar metabolism in fruit during cold storage (Barman et al., 2011). On the opposite side, severe losses of AsA and TA as well as hastening the accumulation of TSS and TSS/TA ratio of untreated fruits (control) could be attributed to the severe increases in respiration rate and ethylene production, which resulted in rapid ripening and senescence of fruits as documented by Barman et al. (2011) and Razzaq et al. (2014).

TABLE 8. Effect of postharvest applications of putrescine (PUT), hydroxypropyl methylcellulose (HPMC) and their incorporations on ascorbic acid content $(\mathrm{mg} / 100 \mathrm{ml}$ juice $)$ of 'Maamoura' guava fruits during cold storage at $7 \pm 1^{\circ} \mathrm{C}$ and $90 \pm 5 \% \mathrm{RH}$

\begin{tabular}{|c|c|c|c|c|c|c|}
\hline \multirow{3}{*}{ Postharvest applications } & \multicolumn{5}{|c|}{ Storage period (days) } & \\
\hline & $\mathbf{0}$ & & 8 & 16 & 24 & \multirow[t]{2}{*}{ Means } \\
\hline & \multicolumn{5}{|c|}{ Season 2016} & \\
\hline Distilled water (control) & $103.60 \mathrm{a}$ & 81.41 & $\mathrm{c}-\mathrm{g}$ & $59.01 \mathrm{i}$ & $44.13 \mathrm{j}$ & $72.04 \mathrm{D}$ \\
\hline $1 \mathrm{mM}$ PUT & $103.60 \mathrm{a}$ & 86.35 & $b-f$ & $72.81 \mathrm{gh}$ & $59.14 \mathrm{i}$ & $80.47 \mathrm{C}$ \\
\hline $2 \mathrm{mM}$ PUT & $103.60 \mathrm{a}$ & 88.27 & b-e & $76.60 \mathrm{e}-\mathrm{h}$ & $66.20 \mathrm{hi}$ & $83.67 \mathrm{BC}$ \\
\hline $5 \%$ HPMC & $103.60 \mathrm{a}$ & 89.64 & bcd & $77.64 \mathrm{~d}-\mathrm{h}$ & $67.67 \mathrm{hi}$ & $84.64 \mathrm{BC}$ \\
\hline $1 \mathrm{mM}$ PUT incorporated with 5\% HPMC & $103.60 \mathrm{a}$ & 92.65 & $a b c$ & $81.78 \mathrm{c}-\mathrm{g}$ & $75.61 \mathrm{fgh}$ & $88.41 \mathrm{AB}$ \\
\hline 2 mM PUT incorporated with 5\% HPMC & $103.60 \mathrm{a}$ & 95.67 & $a b$ & 88.34 b-e & $80.91 \mathrm{c}-\mathrm{g}$ & $92.13 \mathrm{~A}$ \\
\hline \multirow[t]{2}{*}{ Means } & $103.60 \mathrm{~A}$ & 89.00 & B & $76.03 \mathrm{C}$ & $65.61 \mathrm{D}$ & \\
\hline & \multicolumn{5}{|c|}{ Season 2017} & \\
\hline Distilled water (control) & $114.83 \mathrm{a}$ & 83.57 & gh & $63.87 \mathrm{kl}$ & $48.11 \mathrm{~m}$ & $77.60 \mathrm{E}$ \\
\hline $1 \mathrm{mM}$ PUT & $114.83 \mathrm{a}$ & 93.93 & def & $77.42 \mathrm{hi}$ & 61.971 & $87.04 \mathrm{D}$ \\
\hline $2 \mathrm{mM}$ PUT & $114.83 \mathrm{a}$ & 96.79 & $\mathrm{~cd}$ & $80.00 \mathrm{~h}$ & $69.67 \mathrm{jk}$ & $90.32 \mathrm{CD}$ \\
\hline $5 \%$ HPMC & $114.83 \mathrm{a}$ & 98.93 & $\mathrm{~cd}$ & $81.29 \mathrm{~h}$ & $71.21 \mathrm{ij}$ & $91.56 \mathrm{C}$ \\
\hline $1 \mathrm{mM}$ PUT incorporated with 5\% HPMC & $114.83 \mathrm{a}$ & 103.57 & $\mathrm{bc}$ & $88.39 \mathrm{fg}$ & $80.83 \mathrm{~h}$ & $96.90 \mathrm{~B}$ \\
\hline 2 mM PUT incorporated with 5\% HPMC & $114.83 \mathrm{a}$ & 107.14 & & $95.81 \mathrm{de}$ & $88.91 \mathrm{efg}$ & $101.67 \mathrm{~A}$ \\
\hline Means & $114.83 \mathrm{~A}$ & 97.32 & $\mathrm{~B}$ & $81.13 \mathrm{C}$ & $70.12 \mathrm{D}$ & \\
\hline
\end{tabular}

Means followed by the same letters within postharvest applications, storage periods and their interactions in each season are not significantly different at level $P \leq 0.05$ according to Duncan's multiple range test. 
TABLE 9. Effect of postharvest applications of putrescine (PUT), hydroxypropyl methylcellulose (HPMC) and their incorporations on total soluble solids content ( $\left.{ }^{\circ} \mathrm{Brix}\right)$ of 'Maamoura' guava fruits during cold storage at $7 \pm 1^{\circ} \mathrm{C}$ and $90 \pm 5 \% \mathrm{RH}$

\begin{tabular}{|c|c|c|c|c|c|c|c|}
\hline \multirow{3}{*}{ Postharvest applications } & \multicolumn{5}{|c|}{ Storage period (days) } & & \\
\hline & $\mathbf{0}$ & & 8 & 16 & 24 & \multicolumn{2}{|c|}{ Means } \\
\hline & \multicolumn{5}{|c|}{ Season 2016} & & \\
\hline Distilled water (control) & $6.47 \mathrm{i}$ & 8.67 & e & $10.67 \mathrm{a}$ & $9.60 \mathrm{~d}$ & 8.85 & A \\
\hline $1 \mathrm{mM}$ PUT & $6.47 \mathrm{i}$ & 7.93 & $\mathrm{f}$ & $10.60 \mathrm{ab}$ & $10.00 \mathrm{~cd}$ & 8.75 & $\mathrm{AB}$ \\
\hline $2 \mathrm{mM}$ PUT & $6.47 \mathrm{i}$ & 7.80 & fg & $10.47 \mathrm{abc}$ & $10.13 \mathrm{bc}$ & 8.72 & $\mathrm{AB}$ \\
\hline $5 \%$ HPMC & $6.47 \mathrm{i}$ & 7.53 & $\mathrm{fg}$ & $10.47 \mathrm{abc}$ & $10.27 \mathrm{abc}$ & 8.68 & $\mathrm{AB}$ \\
\hline $1 \mathrm{mM}$ PUT incorporated with 5\% HPMC & $6.47 \mathrm{i}$ & 7.37 & gh & $10.33 \mathrm{abc}$ & $10.20 \mathrm{abc}$ & 8.59 & $\mathrm{BC}$ \\
\hline 2 mM PUT incorporated with 5\% HPMC & $6.47 \mathrm{i}$ & 7.07 & $\mathrm{~h}$ & $10.17 \mathrm{bc}$ & $10.13 \mathrm{bc}$ & 8.46 & $\mathrm{C}$ \\
\hline \multirow[t]{2}{*}{ Means } & $6.47 \mathrm{D}$ & 7.73 & $\mathrm{C}$ & $10.45 \mathrm{~A}$ & $10.06 \mathrm{~B}$ & & \\
\hline & \multicolumn{5}{|c|}{ Season 2017} & & \\
\hline Distilled water (control) & 6.801 & 9.00 & $\mathrm{~g}$ & $10.73 \mathrm{a}$ & $9.47 \mathrm{f}$ & 9.00 & A \\
\hline $1 \mathrm{mM}$ PUT & 6.801 & 8.20 & $\mathrm{~h}$ & $10.67 \mathrm{ab}$ & $10.07 \mathrm{e}$ & 8.93 & $\mathrm{AB}$ \\
\hline $2 \mathrm{mM}$ PUT & 6.801 & 7.83 & $\mathrm{i}$ & $10.60 \mathrm{abc}$ & $10.13 \mathrm{de}$ & 8.84 & $\mathrm{ABC}$ \\
\hline $5 \%$ HPMC & 6.801 & 7.70 & ij & $10.60 \mathrm{abc}$ & $10.13 \mathrm{de}$ & 8.81 & $\mathrm{BCD}$ \\
\hline $1 \mathrm{mM}$ PUT incorporated with 5\% HPMC & 6.801 & 7.43 & $\mathrm{jk}$ & $10.47 \mathrm{a}-\mathrm{d}$ & 10.27 cde & 8.74 & $\mathrm{CD}$ \\
\hline 2 mM PUT incorporated with $5 \%$ HPMC & 6.801 & 7.13 & $\mathrm{k}$ & 10.40 a-e & $10.33 \mathrm{~b}-\mathrm{e}$ & 8.67 & $\mathrm{D}$ \\
\hline Means & $6.80 \mathrm{D}$ & 7.88 & $\mathrm{C}$ & $10.58 \mathrm{~A}$ & $10.07 \mathrm{~B}$ & & \\
\hline
\end{tabular}

Means followed by the same letters within postharvest applications, storage periods and their interactions in each season are not significantly different at level $P \leq 0.05$ according to Duncan's multiple range test.

TABLE 10. Effect of postharvest applications of putrescine (PUT), hydroxypropyl methylcellulose (HPMC) and their incorporations on titratable acidity percentage of 'Maamoura' guava fruits during cold storage at $7 \pm 1{ }^{\circ} \mathrm{C}$ and $90 \pm 5 \% \mathrm{RH}$

\begin{tabular}{|c|c|c|c|c|c|c|c|c|c|}
\hline \multirow{3}{*}{ Postharvest applications } & \multicolumn{7}{|c|}{ Storage period (days) } & & \\
\hline & $\mathbf{0}$ & & 8 & & 16 & & 24 & \multicolumn{2}{|c|}{ Means } \\
\hline & \multicolumn{9}{|c|}{ Season 2016} \\
\hline Distilled water (control) & $1.12 \mathrm{a}$ & 0.74 & $\mathrm{~cd}$ & 0.44 & fg & 0.30 & $\mathrm{~g}$ & 0.65 & $\mathrm{C}$ \\
\hline $1 \mathrm{mM}$ PUT & $1.12 \mathrm{a}$ & 0.78 & $\mathrm{~cd}$ & 0.48 & efg & 0.34 & $\mathrm{fg}$ & 0.68 & $\mathrm{BC}$ \\
\hline $2 \mathrm{mM}$ PUT & $1.12 \mathrm{a}$ & 0.81 & $\mathrm{~cd}$ & 0.52 & ef & 0.38 & $\mathrm{fg}$ & 0.71 & $\mathrm{BC}$ \\
\hline $5 \% \mathrm{HPMC}$ & $1.12 \mathrm{a}$ & 0.85 & $\mathrm{bc}$ & 0.64 & de & 0.43 & $\mathrm{fg}$ & 0.76 & $\mathrm{~B}$ \\
\hline $1 \mathrm{mM}$ PUT incorporated with 5\% HPMC & $1.12 \mathrm{a}$ & 0.93 & $a b c$ & 0.80 & $\mathrm{~cd}$ & 0.64 & de & 0.87 & $\mathrm{~A}$ \\
\hline 2 mM PUT incorporated with 5\% HPMC & $1.12 \mathrm{a}$ & 1.01 & $a b$ & 0.88 & $\mathrm{bc}$ & 0.77 & $\mathrm{~cd}$ & 0.94 & A \\
\hline \multirow[t]{2}{*}{ Means } & $1.12 \mathrm{~A}$ & 0.85 & $\mathrm{~B}$ & 0.63 & $\mathrm{C}$ & 0.48 & $\mathrm{D}$ & & \\
\hline & \multicolumn{7}{|c|}{ Season 2017} & & \\
\hline Distilled water (control) & $1.07 \mathrm{a}$ & 0.73 & def & 0.35 & $\mathrm{i}$ & 0.29 & $\mathrm{i}$ & 0.61 & $\mathrm{E}$ \\
\hline $1 \mathrm{mM}$ PUT & $1.07 \mathrm{a}$ & 0.77 & $c-f$ & 0.43 & hi & 0.33 & $\mathrm{i}$ & 0.65 & $\mathrm{DE}$ \\
\hline $2 \mathrm{mM}$ PUT & $1.07 \mathrm{a}$ & 0.81 & b-e & 0.51 & $\mathrm{gh}$ & 0.37 & hi & 0.69 & $\mathrm{CD}$ \\
\hline $5 \%$ HPMC & $1.07 \mathrm{a}$ & 0.85 & bcd & 0.63 & fg & 0.40 & hi & 0.74 & $\mathrm{BC}$ \\
\hline $1 \mathrm{mM}$ PUT incorporated with 5\% HPMC & $1.07 \mathrm{a}$ & 0.90 & $\mathrm{bc}$ & 0.67 & ef & 0.51 & $\mathrm{gh}$ & 0.79 & $\mathrm{AB}$ \\
\hline $2 \mathrm{mM}$ PUT incorporated with 5\% HPMC & $1.07 \mathrm{a}$ & 0.94 & $\mathrm{ab}$ & 0.71 & $\operatorname{def}$ & 0.62 & $\mathrm{fg}$ & 0.83 & A \\
\hline Means & $1.07 \mathrm{~A}$ & 0.83 & $\mathrm{~B}$ & 0.55 & $\mathrm{C}$ & 0.42 & $\mathrm{D}$ & & \\
\hline
\end{tabular}

Means followed by the same letters within postharvest applications, storage periods and their interactions in each season are not significantly different at level $P \leq 0.05$ according to Duncan's multiple range test. 
TABLE 11. Effect of postharvest applications of putrescine (PUT), hydroxypropyl methylcellulose (HPMC) and their incorporations on total soluble solids/titratable acidity ratio of 'Maamoura' guava fruits during cold storage at $7 \pm 1^{\circ} \mathrm{C}$ and $90 \pm 5 \% \mathrm{RH}$

\begin{tabular}{|c|c|c|c|c|c|c|}
\hline \multirow{3}{*}{ Postharvest applications } & \multicolumn{5}{|c|}{ Storage period (days) } & \multirow{3}{*}{ Means } \\
\hline & $\mathbf{0}$ & & 8 & 16 & 24 & \\
\hline & \multicolumn{5}{|c|}{ Season 2016} & \\
\hline Distilled water (control) & $5.79 \mathrm{j}$ & 11.83 & $f-i$ & $24.77 \mathrm{~cd}$ & $33.25 \mathrm{a}$ & $18.91 \mathrm{~A}$ \\
\hline $1 \mathrm{mM}$ PUT & $5.79 \mathrm{j}$ & 10.30 & $g-j$ & $22.08 \mathrm{~cd}$ & $30.38 \mathrm{ab}$ & $17.14 \mathrm{AB}$ \\
\hline $2 \mathrm{mM}$ PUT & $5.79 \mathrm{j}$ & 9.72 & $g-j$ & $20.36 \mathrm{de}$ & $26.39 \mathrm{bc}$ & $15.57 \mathrm{BC}$ \\
\hline $5 \%$ HPMC & $5.79 \mathrm{j}$ & 8.87 & $g-j$ & 16.46 ef & $24.44 \mathrm{~cd}$ & $13.89 \mathrm{C}$ \\
\hline $1 \mathrm{mM}$ PUT incorporated with 5\% HPMC & $5.79 \mathrm{j}$ & 7.97 & hij & $14.57 \mathrm{fg}$ & 16.42 ef & $11.19 \mathrm{D}$ \\
\hline 2 mM PUT incorporated with $5 \%$ HPMC & $5.79 \mathrm{j}$ & 7.03 & $\mathrm{ij}$ & $11.84 \mathrm{f}-\mathrm{i}$ & $13.46 \mathrm{fgh}$ & $9.53 \mathrm{D}$ \\
\hline \multirow[t]{2}{*}{ Means } & $5.79 \mathrm{D}$ & 9.29 & $\mathrm{C}$ & $18.35 \mathrm{~B}$ & $24.06 \mathrm{~A}$ & \\
\hline & \multicolumn{5}{|c|}{ Season 2017} & \\
\hline Distilled water (control) & $6.40 \mathrm{~m}$ & 12.50 & i-1 & $30.28 \mathrm{abc}$ & $33.62 \mathrm{a}$ & $20.70 \mathrm{~A}$ \\
\hline $1 \mathrm{mM}$ PUT & $6.40 \mathrm{~m}$ & 10.95 & $\mathrm{j}-\mathrm{m}$ & $25.01 \mathrm{def}$ & $30.58 \mathrm{ab}$ & $18.24 \mathrm{~B}$ \\
\hline 2 mM PUT & $6.40 \mathrm{~m}$ & 10.02 & $\mathrm{klm}$ & 20.96 efg & $28.20 \mathrm{bcd}$ & $16.40 \mathrm{BC}$ \\
\hline $5 \%$ HPMC & $6.40 \mathrm{~m}$ & 9.09 & $\operatorname{lm}$ & $16.95 \mathrm{ghi}$ & 25.67 cde & $14.53 \mathrm{CD}$ \\
\hline $1 \mathrm{mM}$ PUT incorporated with $5 \%$ HPMC & $6.40 \mathrm{~m}$ & 8.42 & $\operatorname{lm}$ & $15.74 \mathrm{hij}$ & $20.30 \mathrm{fgh}$ & $12.72 \mathrm{DE}$ \\
\hline $2 \mathrm{mM}$ PUT incorporated with 5\% HPMC & $6.40 \mathrm{~m}$ & 7.64 & $\operatorname{lm}$ & $14.92 \mathrm{ijk}$ & $16.75 \mathrm{ghi}$ & $11.43 \mathrm{E}$ \\
\hline Means & $6.40 \mathrm{D}$ & 9.77 & $\mathrm{C}$ & $20.64 \mathrm{~B}$ & $25.86 \mathrm{~A}$ & \\
\hline
\end{tabular}

Means followed by the same letters within postharvest applications, storage periods and their interactions in each season are not significantly different at level $P \leq 0.05$ according to Duncan's multiple range test.

The above findings are in agreement with that of PUT application on apricots (MartínezRomero et al., 2002), plums (Serrano et al., 2003), pomegranates (Mirdehghan et al., 2007), plums (Khan et al., 2008) and mangoes (Malik \& Singh, 2005, Jawandha et al., 2012 and Razzaq et al., 2014). Moreover, 'Mridula' pomegranate fruit treated with PUT alone or plus carnauba wax retained AsA and TA contents of fruits as well as reduced the accumulation of TSS during cold storage period for 60 days at $3^{\circ} \mathrm{C}$ plus 3 days at $20^{\circ} \mathrm{C}$ in comparison to untreated fruits (Barman et al., 2011). In addition, edible composite coatings based on HPMC, beeswax and food preservatives maintained tomatoes content of TA during cold storage at $5^{\circ} \mathrm{C}$ for 15 days followed by seven days shelf life at $20^{\circ} \mathrm{C}$ (Fagundes et al., 2014).

Effect of postharvest applications of putrescine (PUT), hydroxypropyl methylcellulose (HPMC) and their incorporations on shelf life period (days) of 'Maamoura' guava fruits stored at $7 \pm 1^{\circ} \mathrm{C}$ and $90 \pm 5 \% R H$

Data tabulated in Table 12 show that all postharvest applications of 'Maamoura' guavas prolonged shelf life period at ambient conditions $\left(25 \pm 2^{\circ} \mathrm{C}\right.$ and $65 \pm 5 \%$ RH) as compared to untreated fruits (control). These results indicated that the longest shelf life period was attained by guavas treated with $2 \mathrm{mM}$ PUT incorporated with Egypt. J. Hort. Vol. 45, No.2 (2018)
5\% HPMC (8.67 \& 8.33 days) in 2016 and 2017 seasons, respectively followed by fruits treated with $1 \mathrm{mM}$ PUT incorporated with 5\% HPMC (8.33 \& 7.67 days) in the first and second seasons, respectively. On contrary, the shortest shelf life period (1.67 and 2.00 days) in 2016 and 2017 seasons, respectively were recorded for untreated fruits (control).

The longest shelf life period was for 'Maamoura' guavas treated with PUT, HPMC and their incorporated and this could be attributed to delaying the progress of the ripening and senescence processes reported by Mondal (2005) and Malik \& Singh (2005). In this respect, postharvest application of PUT has been demonstrated to prolonged shelf life of apricots (Martínez-Romero et al., 2002), plums (Serrano et al., 2003), pomegranates (Mirdehghan et al., 2007) and mangoes (Malik \& Singh, 2005). In addition, the application of different coating formulations containing carnauba wax, shellac, zein and cellulose derivatives especially coatings based upon HPMC increased shelf life period of 'Kent' 'Tommy Atkins' and 'Lirfa' mangoes as compared to uncoated fruits be delaying ripening process (Hoa et al., 2002). Moreover, the application of HPMC improved shelf life of 'Tommy Atkins' mangoes in comparison to uncoated fruits (Baldwin et al., 1999). 
TABLE 12. Effect of postharvest applications of putrescine (PUT), hydroxypropyl methylcellulose (HPMC) and their incorporations on shelf life period (days) of 'Maamoura' guava fruits stored at $7 \pm 1^{\circ} \mathrm{C}$ and $\mathbf{9 0} \pm \mathbf{5 \%}$ RH

\begin{tabular}{|c|c|c|c|}
\hline \multirow{2}{*}{$\frac{\text { Postharvest applications }}{\text { Distilled water (control) }}$} & \multirow{2}{*}{$\frac{\text { Season } 2016}{1.67 \mathrm{~d}}$} & \multicolumn{2}{|c|}{ Season 2017} \\
\hline & & 2.00 & $\mathrm{c}$ \\
\hline $1 \mathrm{mM}$ PUT & $3.67 \mathrm{c}$ & 4.00 & $\mathrm{~b}$ \\
\hline $2 \mathrm{mM}$ PUT & $4.33 \mathrm{c}$ & 4.33 & $\mathrm{~b}$ \\
\hline $5 \%$ HPMC & $5.67 \mathrm{~b}$ & 5.33 & $\mathrm{~b}$ \\
\hline $1 \mathrm{mM}$ PUT incorporated with 5\% HPMC & 8.33 a & 7.67 & a \\
\hline $2 \mathrm{mM}$ PUT incorporated with 5\% HPMC & $8.67 \mathrm{a}$ & 8.33 & a \\
\hline
\end{tabular}

Means followed by the same letters within postharvest applications in each season are not significantly different at level $P \leq 0.05$ according to Duncan's multiple range test.

\section{Conclusion}

In general, our results showed positive influence of both postharvest applications and their combinations on maintaining quality attributes of 'Maamoura' guavas during cold storage. The combined treatments of putrescine (PUT) at 1 or $2 \mathrm{mM}$ and hydroxypropyl methylcellulose (HPMC) coating at 5\% were more potent. These applications significantly decreased physiological loss in weight and reduced decay incidence as well as maximized marketable percentage, maintained visual appearance score and retarded fruit softening during cold storage period at $7^{\circ} \mathrm{C}$. Moreover, these applications delayed colour development by significantly retained total chlorophyll content and maintained fruit contents in vitamin $\mathrm{C}$ and titratable acidity as well as slowed the accumulation of fruit contents in total soluble solids and total soluble solids/titratable acidity ratio than untreated fruits (control) during cold storage period. Ultimately, these applications significantly prolonged shelf life period at ambient conditions $\left(25 \pm 2{ }^{\circ} \mathrm{C}\right.$ and $\left.65 \pm 5 \% \mathrm{RH}\right)$ after end of cold storage period ( 24 days) as compared to control. The attained results could be attributed to the effect of both treatments in reducing ethylene production, respiration and thus delaying ripening and finally senescence of 'Maamoura' guava fruits.

Acknowledgements: the author is grateful to Asma Abou-Ismail, MSc. for her indispensable technical support. Also, the author gratefully acknowledge Prof. Dr. M.A.A. Mohamed professor of postharvest physiology for critical revision of this manuscript.
Funding statements: the author declares that there is no received external funding for this study.

Conflicts of interest: the author declares that there are no conflicts of interest related to the publication of this study.

\section{References}

Anonymous, (2017) Ministry of agriculture and land reclamation, economic affairs sector, bulletin of the agricultural statistics.

AOAC (2005) Official Method of Analysis of Association of Official Analytical Chemist International. $18^{\text {th }}$ ed., North Frederick Avenue, Gaithersburg, Maryland, USA.

Baldwin, E.A., Burns, J.K., Kazokas, W., Brecht, J.K., Hagenmaier, R.D., Bender, R.J. and Pesis, E. (1999) Effect of two edible coatings with different permeability characteristics on mango (Mangifera indica L.) ripening during storage. Postharvest Biology and Technology, 17, 215226.

Barman, K., Ram, A. and Pal, R.K. (2011) Putrescine and carnauba wax pretreatments alleviate chilling injury, enhance shelf life and preserve pomegranate fruit quality during cold storage. Scientia Horticulturae, 130, 795-800.

Davey, M.W., Van Montagu, M., Inze, D., Sanmartin, M., Kanellis, A. and Smirnoff, N. (2000) Plant L-ascorbic acid: chemistry, function, metabolism, bioavailability and effects of processing. Journal of Science Food and Agriculture, 80, 825-860.

Egypt. J. Hort. Vol. 45, No. 2 (2018) 
Dhall, R.K. (2013) Advances in edible coatings for fresh fruits and vegetables: a review. Critical Reviews in Food Science and Nutrition, 53 (5), 435-450.

Duncan, D.B. (1955) Multiple range and multiple F-test. Biometrics, 11, 1-42.

Fagundes, C., Palou, L., Monteiro, A.R. and Pérez-Gago, M.B. (2014) Effect of antifungal hydroxypropyl methylcellulose-beeswax edible coatings on gray mold development and quality attributes of coldstored cherry tomato fruit. Postharvest Biology and Technology, 92, 1-8.

Hoa, T.T., Ducamp, M.N., Lebrun, M. and Baldwin, E.A. (2002) Effect of different coating treatments on the quality of mango fruit. Journal of Food Quality, 25, 471-486.

Jain, N., Dhawan, K., Malhotra, S. and Singh, R. (2003) Biochemistry of fruit ripening in guava (Psidium guajava L.) compositional and enzymatic changes. Plant Foods for Human Nutrition, 58, 309-315.

Jawandha, S.K., Gill, M.S., Singh, N., Gill, P.P.S. and Singh, N. (2012) Effect of post-harvest treatments of putrescine on storage of mango cv. Langra. African Journal of Agricultural Research, 48, 6432-6436.

Kader, A.A. (2002) Postharvest biology and technology: an overview. In: Kader, A.A. (Edition), postharvest technology of horticultural crops, 3311, $3^{\text {rd }}$ ed., University of California, ANR, Publication, Oakland, California, 39-47.

Khan, A.S., Singh, Z. and Abbasi, N.A. (2007) Prestorage putrescine application suppresses ethylene biosynthesis and retards fruit softening during low temperature storage in 'Angelino' plum. Postharvest Biology and Technology, 46, 36-46.

Khan, A.S., Singh, Z., Abbasi, N.A. and Swinny, E.E. (2008) Pre-or post-harvest applications of putrescine and low temperature storage affect fruit ripening and quality of 'Angelino' plum. Journal of Science Food and Agriculture, 88, 1686-1695.

Khosroshahi, M.R.Z. and Esna-ashari, M. (2007) Postharvest putrescine extend the storage-life of apricot (Prunus armeniaca L.) 'Tokhmsefid' fruit. Journal of Horticultural Science and Biotechnology, 82, 986-990.

Malik, A.U. and Singh, Z. (2005) Pre-storage application of polyamines improves shelf-life and fruit quality of mango. Journal of Horticultural Science and Biotechnology, 80, 363-369.

Egypt. J. Hort. Vol. 45, No.2 (2018)
Martínez-Romero, D., Serrano, M., Carbonell, A., Brugos, L., Riquelme, F. and Valero, D. (2002) Effects of postharvest putrescine treatment on extending shelf life and reducing mechanical damage in apricot. Journal of Food Science, 67 (5), 1706-1712.

Martínez-Romero, D., Valero, D., Serrano, M., Burló, F., Carbonell, A., Burgos, L. and Riquelme, F. (2000) Exogenous polyamines and gibberellic acid effects on peach (Prunus persica L.) storability improvement. Journal of Food Science, 65 (2), 288-294.

Mercado-Silva, E., Benito-Bautista, P. and GarciaVelasco, M.A. (1998) Fruit development, harvest index and ripening changes of guavas produced in central Mexico. Postharvest Biology and Technology, 13, 143-150.

Mirdehghan, S.H., Rahemi, M., Castillo, S., MartínezRomero, D., Serrano, M. and Valero, D. (2007) Pre-storage application of polyamines by pressure or immersion improves shelf-life of pomegranate stored at chilling temperature by increasing endogenous polyamine levels. Postharvest Biology and Technology, 44, 26-33.

Mondal, K. (2005) Antagonistic effect of polyamines on ripening related biochemical changes in guava (Psidium guajava L.). Ph.D Thesis. Department of Biochemistry, CCS Haryana Agricultural University, Hisar, India.

Morris, S.M. (2009) Recent advances in arginine metabolism: roles and regulation of the arginases. British Journal of Pharmacology, 157, 922-930.

M-STAT, (1993) A microcomputer program for the design, arrangement and analysis of agronomic research experiments. Michigan State University.

Navarro-Tarazaga, M.L., del Río, M.A., Krochta, J.M. and Pérez-Gago, M.B. (2008) Fatty acid effect on hydroxypropyl methylcellulose-bees wax edible film properties and postharvest quality of coated 'Ortanique' mandarins. Journal of Agricultural and Food Chemistry, 56 (22), 10689-10696.

Olivas, G.L., Davila-Avina, J.E., Salas-Salazar, N.A. and Molina. F.J. (2008) Use of edible coatings to preserve the quality of fruits and vegetables during storage. Stewart Postharvest Review, 3 (6), 1-10.

Paksasorn, A., Hayasaka, T., Matsui, H., Ohara, H. and Hirata, N. (1995) Relationship of polyamine to ACC content and ethylene evolution in Japanese apricot fruit. Journal of the Japanese Society for Horticultural Science, 63, 761-766. 
Pandey, S., Ranade, S.A., Nagar, P.K. and Kumar, N. (2000) Role of polyamines and ethylene as modulators of plant senescence. Journal of Biosciences, 25 (3), 291-299.

Payasi, A., Mishra, N.N., Chaves, A.L.S. and Singh, R. (2009) Biochemistry of fruit softening: an overview. Physiology and Molecular Biology of Plants, 15, 103-113.

Pérez-Gago, M.B., Rojas, C. and del Río, M.A. (2002) Effect of lipid type and amount of edible hydroxypropyl methylcellulose-lipid composite coatings used to protect postharvest quality of mandarins cv. Fortune. Journal of Food Science, 67 (8), 2903-2910.

Pérez-Gutiérrez, R.M., Mitchell, S. and Vargas-Solis, R. (2008) Psidium guajava: a review of its traditional uses, phytochemistry and pharmacology. Journal of Ethnopharmacology, 117 (1), 1-27.

Razzaq, K., Khan, A.S., Malik, A.U., Shahid, M. and Ullah, S. (2014) Role of putrescine in regulating fruit softening and antioxidative enzyme systems in 'Samar Bahisht Chaunsa' mango. Postharvest Biology and Technology, 96, 23-32.

Reyes, M.U. and Paul, R.E. (1995) Effects of storage temperature and ethylene treatments of guava (Psuidium guajava L) fruit ripening. Postharvest Biology and Technology, 6, 357-365.

Serrano, M., Martínez-Romero, D., Guillen, F. and Valero, D. (2003). Effects of exogenous putrescine on improving shelf life of four plum cultivars. Postharvest Biology and Technology, 30, 259-271.

Smith, T.A. (1985) Polyamines. Annual Review of Physiology, 36, 117-143.

Tripathi, P. and Dubey, N.K. (2004) Exploitation of natural products as an alternative strategy to control postharvest fungal rotting of fruit and vegetables. Postharvest Biology and Technology, 32, 235-245.

Valencia-Chamorro, S.A., Palou, L., del Río, M.A. and Pérez-Gago, M.B. (2008) Inhibition of Penicillium digitatum and Penicillium italicum by hydroxypropyl methylcellulose-lipid edible composite films containing food additives with antifungal properties. Journal of Agricultural and Food Chemistry, 56 (23), 11270-11278.
Valencia-Chamorro, S.A., Palou, L., del Río, M.A. and Pérez-Gago, M.B. (2011) Performance of hydroxypropyl methylcellulose (HPMC)-lipid edible coatings with antifungal food additives during cold storage of 'Clemenules' mandarins. LWT-Food Science and Technology, 44, 23422348.

Valencia-Chamorro, S.A., Pérez-Gago, M.B., del Río, M.A. and Palou, L. (2009) Effect of antifungal hydroxypropyl methylcellulose (HPMC)-lipid edible composite coatings on postharvest decay development and quality attributes of cold-stored 'Valencia' oranges. Postharvest Biology and Technology, 54 (2), 72-79.

Valero, D., Martínez-Romero, D. and Riquelme, F. (1998). Influence of postharvest treatment with putrescine and calcium on endogenous polyamines, firmness, and abscisic acid in lemon (Citrus lemon L. Burm cv. Verna). Journal of Agricultural and Food Chemistry, 46, 2102-2109.

Valero, D., Martínez-Romero, D. and Serrano, M. (2002) The role of polyamines in the improvement of the shelf life of fruit. Trends in Food Science and Technology, 13, 228-234.

Walters, D.R. (2003) Polyamines and plant disease. Phytochemistry, 64, 97-107.

Watkins, C. and Harman, J. (1981) Use of penetrometer to measure flesh firmness of fruit. Orchadist, N.Z., 14-16.

Wellburn, A.R. (1994) The spectral determination of chlorophylls $a$ and $b$, as well as total carotenoids, using various solvents with spectrophotometers of different resolution. Journal of Plant Physiology, 144, 307-313.

Wills, R.H., McGlasson, B., Graham, D. and Joyce, D. (1998) Postharvest: an introduction to the physiology and handling of fruit, vegetables and ornamentals. (4 $4^{\text {th }}$ Edition). CAP International, Wallingford Oxen 108DE, UK., 4, 262 p.

Woods, J.L. (1990) Moisture loss from fruits and vegetables. Postharvest news and information, 1 (3), 195-199.

(Received 20/04/2018, accepted 24/06/2018) 
تأثير بعض معاملات ما بعد الحصاد الآمنة علي الجودة وإطالة عمر ثمار الجوافة أثناء التخزين المبرد

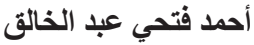

قسم البساتين - كلية الزر اعة - جامعة طنطا - مصر.

على الر غم من التوسع في المساحات المزرو عة من الجو افة، لا يز ال التحسن في جودة ما ما بعد الحصاد مهملاً.

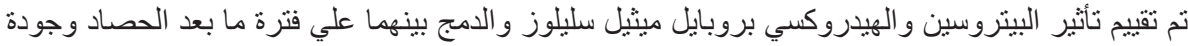

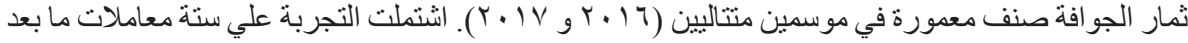

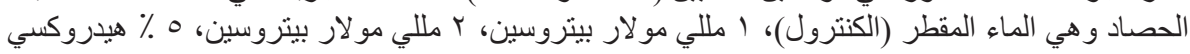

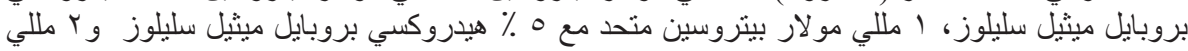

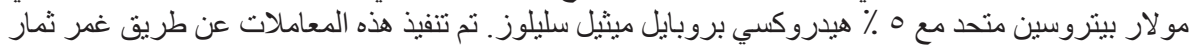

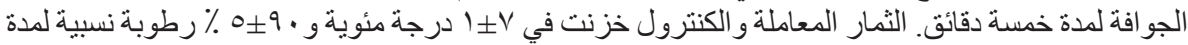

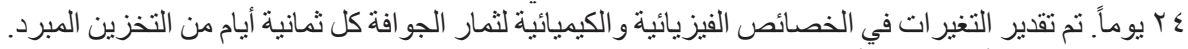

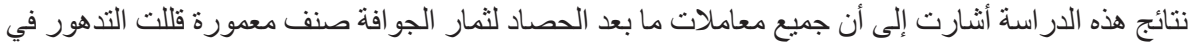

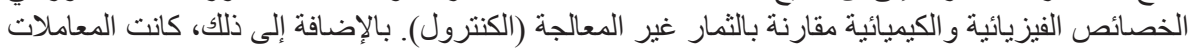

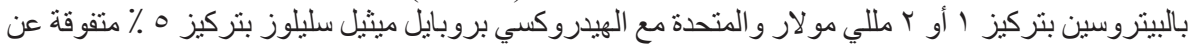

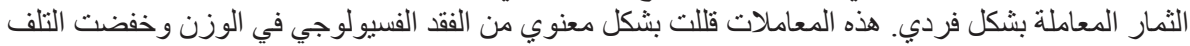

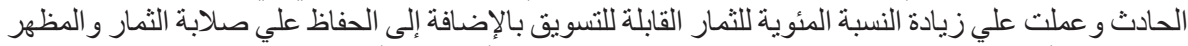

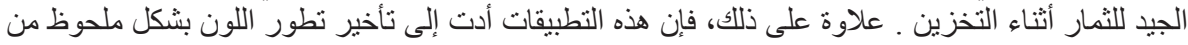

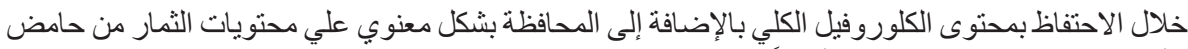

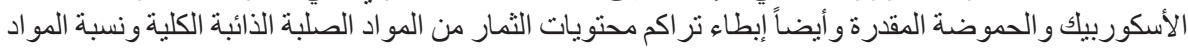

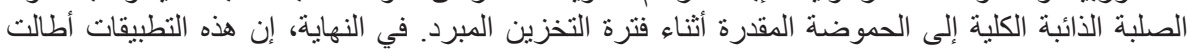

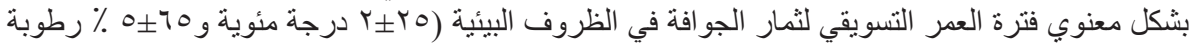

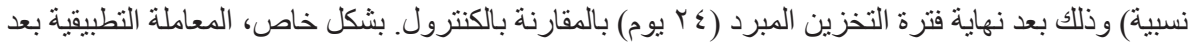

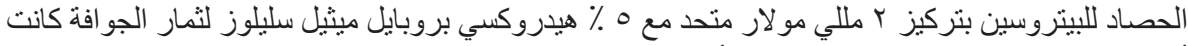

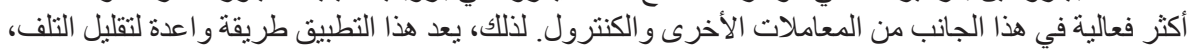
الحفاظ على الجودة و إطالة فترة حياة ما بعد الحصاد الثمار الجو افة صنف معمورة الثئ أثناء التخزين المبرد. 